\title{
Natural-origin polymers as carriers and scaffolds for biomolecules and cell delivery in tissue engineering applications ${ }^{\text {th }}$
}

\author{
Patrícia B. Malafaya ${ }^{*, 1}$, Gabriela A. Silva ${ }^{1}$, Rui L. Reis \\ 3B's Research Group - Biomaterials, Biodegradables and Biomimetics, Department of Polymer Engineering, University of Minho, \\ Campus de Gualtar, 4710-057 Braga, Portugal \\ IBB - Institute for Biotechnology and Bioengineering, PT Government Associated Laboratory, Portugal
}

Received 31 January 2007; accepted 28 March 2007

Available online 6 April 2007

\begin{abstract}
The present paper intends to overview a wide range of natural-origin polymers with special focus on proteins and polysaccharides (the systems more inspired on the extracellular matrix) that are being used in research, or might be potentially useful as carriers systems for active biomolecules or as cell carriers with application in the tissue engineering field targeting several biological tissues. The combination of both applications into a single material has proven to be very challenging though. The paper presents also some examples of commercially available natural-origin polymers with applications in research or in clinical use in several applications. As it is recognized, this class of polymers is being widely used due to their similarities with the extracellular matrix, high chemical versatility, typically good biological performance and inherent cellular interaction and, also very significant, the cell or enzyme-controlled degradability. These biocharacteristics classify the natural-origin polymers as one of the most attractive options to be used in the tissue engineering field and drug delivery applications.
\end{abstract}

(C) 2007 Elsevier B.V. All rights reserved.

Keywords: Natural-origin polymers; Drug delivery; Cell delivery; Tissue engineering; Regenerative medicine; Growth factors; Biomolecules; Scaffolds; Carriers

\section{Contents}

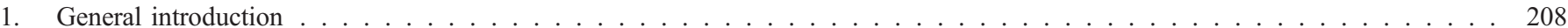

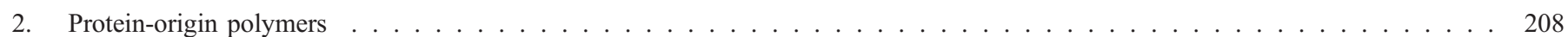

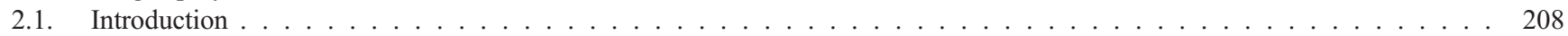

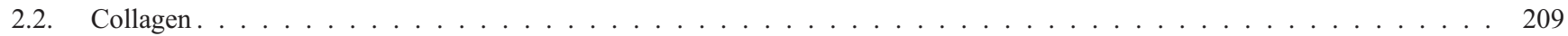

2.3. Gelatin . . . . . . . . . . . . . . . . . . . . . . . . . . . 210

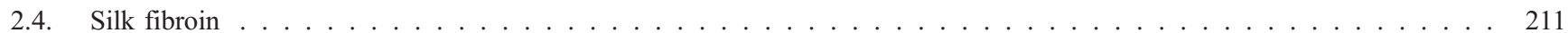

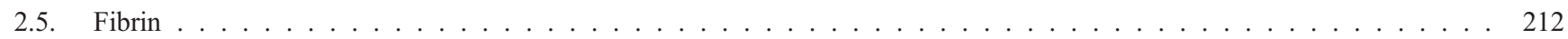

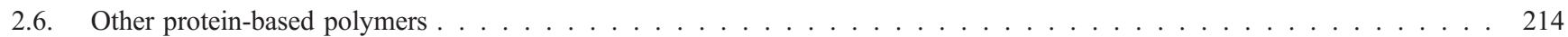

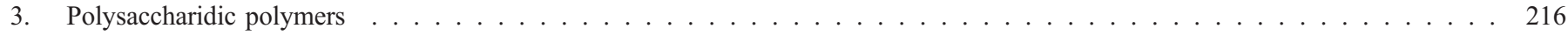

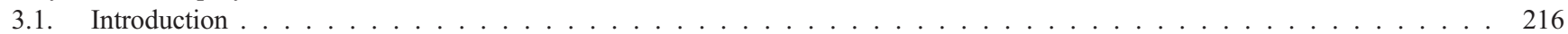

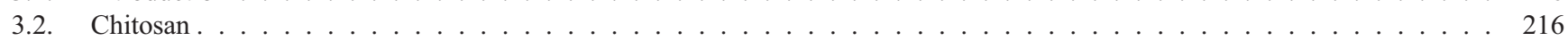

\footnotetext{
is This review is part of the Advanced Drug Delivery Reviews theme issue on "Matrices and Scaffolds for Drug Delivery in Tissue Engineering".

* Corresponding author. 3B's Research Group - Biomaterials, Biodegradables and Biomimetics, Department of Polymer Engineering, University of Minho, Campus de Gualtar, 4710-057 Braga, Portugal. Tel.: +351 253604 783/2; fax: +351 253604498

E-mail address: pmalafaya@dep.uminho.pt (P.B. Malafaya).

URLs: http://www.3bs.uminho.pt (P.B. Malafaya), http://www.3bs.uminho.pt (G.A. Silva), http://www.3bs.uminho.pt (R.L. Reis).

1 Equally contributing authors.
} 


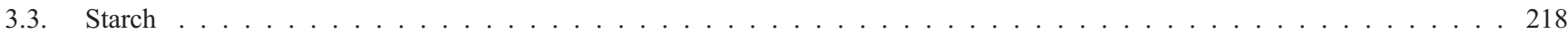

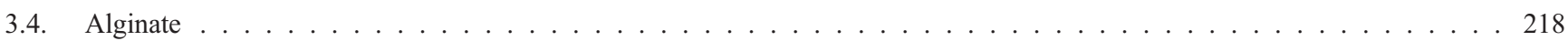

3.5. Hyaluronan .. . . . . . . . . . . . . . . . . . . . . . . . . . . . . . . . . . . . . 221

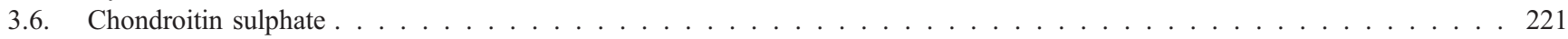

3.7. Other polysaccharidic polymers . . . . . . . . . . . . . . . . . . . . . . . . . . . . . . . . 223

4. Polyhydroxyalkanoates ..... . . . . . . . . . . . . . . . . . . . . . . . . . . . . . . . . . 225

5. Final remarks and future directions . . . . . . . . . . . . . . . . . . . . . . . . . . . . . . . . . . . . . . . . 225

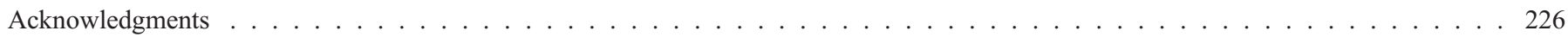

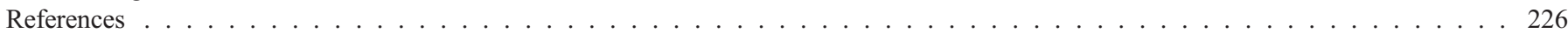

\section{General introduction}

Tissue engineering is the promising therapeutic approach that combines cells, biomaterials, and microenvironmental factors to induce differentiation signals into surgically transplantable formats and promote tissue repair and/or functional restoration. Despite many advances, tissue engineers still face significant challenges in repairing or replacing tissues that serve predominantly biomechanical functions such as articular cartilage. One obstacle can be identified as the scaffolds play an important role as the extracellular matrix but they are often unable to create the exact/correct microenvironment during the engineered tissue development to promote the accurate in vitro tissue development. The emerging and promising next generation of engineered tissues is relying on producing scaffolds with an informational function, e.g., material containing growth factors sequence which facilitates cell attachment, proliferation and differentiation that is far better than non-informational polymers. The use of growth factors has been considered as a way to manipulate not only the host healing response at the site of injury to facilitate the tissue repair, but also to manipulate and improve the in vitro tissue growth in order to produce more biofunctional engineered tissues. Hence, the strategy is to mimic matrix and provide the necessary information or signaling for cell attachment, proliferation and differentiation to meet the requirement of dynamic reciprocity for tissue engineering. This justifies the importance of drug delivery in tissue engineering applications.

Moreover, natural polymers perform a diverse set of functions in their native setting. For example, polysaccharides function in membranes and intracellular communication and also as storage, and proteins function as structural materials and catalysts [1]. The current trend is to mimic nature and what better way than materials from nature to do it? Natural biopolymers illustrate, as an impressive example, how all the properties displayed by biological materials and systems are exclusively determined by the physical-chemical properties of the monomers and their sequence. A well-defined molecular structure can lead to a rich complexity of structure and function on the mesoscale [2]. Here, competing interactions, structural flexibility and functional properties are tailored by the succession of monomeric units taken from a rather limited set. Because macromolecules bridge the span of nanometers up to micrometers by virtue of their length and flexibility, they enable a unique control of hierarchical organization and long-range interactions. Regardless of the tissue/organ involved, there are many concepts that can be extrapolated from nature and therefore applicable in the tissue engineering field to repair/ regenerate the tissue/organ. In many cases, the matrices and scaffolds would ideally be made of biodegradable polymers whose properties closely resemble those of the extracellular matrix (ECM), a soft, tough, and elastomeric proteinaceous network that provides mechanical stability and structural integrity to tissues and organs [3].

If the constantly evolving knowledge on how our body works and the needs to achieve repair, there is the need to congregate into a sole construct both structural support and drug delivery properties. For the purpose of this review, cell encapsulation will be considered as a delivery system, as this is believed to be a promising therapeutic approach. Encapsulation physically isolates a cell mass from an outside environment and aims to maintain normal cellular physiology within a desired permeability barrier [4]. Encapsulation techniques are generally classified as microencapsulation (involving small spherical vehicles and conformal coated tissues) and macroencapsulation (involving larger flat-sheet and hollow-fiber membranes) [4]. The encapsulated cells can then be cultured in vitro or transplanted in vivo, either to repopulate a defect site or to produce growth factors or other molecules that will have an effect over the targeted cell population. Within the latter, cells have been transfected with genes of interest (including BMPs, among others) to make them true cellular factories to produce and deliver active growth factors.

\section{Protein-origin polymers}

\subsection{Introduction}

In this paper, the attention is focused in several protein-based polymers that found application in research works for drug or cell delivery within the tissue engineering field, namely collagen, gelatin, silk fibroin, fibrin (fibrinogen) and other proteins such elastin or soybean. These protein-based polymers and their applications in the field are described in more detail in the following sections.

Protein-based polymers have the advantage of mimicking many features of extracellular matrix and thus have the potential to direct the migration, growth and organization of cells during tissue regeneration and wound healing and for stabilization of encapsulated and transplanted cells. In a molecular perspective, 
proteins may be considered as polymer structures composed by 20 distinct amino acids linked by amide (or peptide) bonds. Amino acids are therefore the building blocks of polypeptides and proteins, which consist of a central carbon linked to an amine group, a carboxyl group, a hydrogen atom, and a side chain ( $\mathrm{R}$ groups). $\mathrm{R}$ groups can be classified as non-polar groups, uncharged polar groups or charged polar groups, and their distribution along the protein backbone renders proteins with distinct characteristics.

One of the drawbacks of the natural-origin polymers is their possible batch variation. One interesting strategy to overcome this issue is the recombinant protein technologies where the monodispersity and precisely defined properties of polymers as well as the predictable placement of crosslinking groups, binding moieties at specific sites along the polypeptide chain or their programmable degradation rates makes them very attractive and useful for drug delivery and tissue engineering [2]. One example is presented when describing the elastin like polypeptides. Our attempt to mimic nature to create materials is routinely accomplished with exceptional high yield and efficiency by the cellular systems of protein biosynthesis. Protein biosynthesis is implemented with an absolute control of the amino-acid sequence $[2,5,6]$, from the first amino acid to the last, with complete absence of randomness. Additionally, the protein biosynthesis machinery is able to process and produce any amino-acid sequence stored in the elements of information called genes, so its flexibility is absolute. If one controls the information that genes deliver into the machinery, one completely controls the biosynthesis process itself. The key issue to retain is to use highly purified and defined polymers in order to have the perfect control over the developed final product.

\subsection{Collagen}

Collagen is regarded by many as an ideal scaffold or matrix for tissue engineering as it is the major protein component of the extracellular matrix, providing support to connective tissues such as skin, tendons, bones, cartilage, blood vessels, and ligaments [7-11]. In its native environment, collagen interacts with cells in connective tissues and transduces essential signals for the regulation of cell anchorage, migration, proliferation, differentiation, and survival [12]. Twenty-seven types of collagens have been identified to date, but collagen type I is the most abundant and the most investigated for biomedical applications. The different collagens are first synthesized as large precursor molecules known as procollagens [13]. After secretion of procollagen into the extracellular matrix, both $C$ and $N$-propeptides are cleaved and the molecules then selfassemble into fibrils (a detailed review can be found in [12]). Fibril-forming collagen molecules used in tissue engineering applications consist of three polypeptide chains of glycine-X-Y (Gly-X-Y) amino acid repeats twined around one another to form triple helices [14,15]. Collagen is defined by high mechanical strength, good biocompatibility, low antigenicity and ability of being crosslinked, and tailored for its mechanical, degradation and water-uptake properties. Collagen is mainly isolated from animal tissues, and an additional concern has been raised about the safety of the collagen derived from animal tissues, based on the potential for viral and prion contamination. However, purification techniques using enzymatic treatments may be employed to eliminate the immunogenic telopeptides, the major cause of foreign body response $[16,17]$, as well as the development of recombinant and nonrecombinant human collagens as a replacement for animal tissue-derived material. However, alternatives to animal origin collagens - those produced by recombinant technologies - still present a high cost. Additionally, collagen is hard to process and the extent and rate of degradability is hard to control. For the latter, several factors have an impact on degradability of collagen, for instance, the penetration of cells into the structure causes contraction, as well as the fact that, besides collagenase and gelatinase, several other non-specific proteinases are able to digest collagen [18]. Crosslinking is necessary in order to tailor the degradation of collagen and this has obviously to have into account the application, as fluid movement, pressure and nature of the tissue where the material is implanted contribute to a faster degradation rate. In addition to the difficulties in processability, the sterilization of collagen is also a problem, as nearly all sterilization methods incur some degree of alteration of collagen [18].

Collagen has been widely applied in tissue engineering applications and in some extent in delivery systems in this field. Table 1 intends to summarize some relevant applications reported as research works.

Recently, a broad range of tissue engineering products based on animal-sourced collagen scaffolds have been developed and commercialized. For example, bilayered collagen gels seeded with human fibroblasts in the lower part and human keratinocytes in the upper layer have been used as the 'dermal' matrix of an artificial skin product are commercialized by Organogenesis in USA under the name of Apligraf ${ }^{\circledR}$ and was the first bio-engineered skin to receive FDA approval in 1998. Organogenesis has other collagen-based products currently under development such as Revitix ${ }^{\mathrm{TM}}$ (topical cosmetic product), VCTO1 ${ }^{\mathrm{TM}}$ (bilayered bio-engineered skin) or FortaDerm $^{\mathrm{TM}}$ Antimicrobial (anti-microbial wound dressing). inFUSE ${ }^{\circledR}$ Bone Graft are collagen sponges have been used as an osteoconductive carrier of bone morphogenetic protein (BMP-2) for spinal fusion marketed by Medtronic Sofamor Danek in USA. Collagen sponges have been use also for the treatment of long bone fractures [12]. Collagraft ${ }^{\circledR}$ commercialized by Angiotech Pharmaceuticals, Inc. in Canada is a mixture of porous hydroxylapatite and tricalcium phosphate and animalderived collagen I, has been used clinically for the treatment of long bone fractures for more than a decade. Healos ${ }^{\circledR}$ Bone Graft Replacement marketed by DePuy Orthopaedics in USA is an osteoconductive matrix constructed of crosslinked collagen fibers that are fully coated with hydroxylapatite and has been approved recently for clinical use as a bone graft substitute in spinal fusions [12] and Biomend ${ }^{\circledR}$ is a collagen membrane conventionally used in the regeneration of periodontal tissue and is a registered trademark of Integra LifeSciences Corp. in USA [36]. 
Table 1

Collagen-based matrices/scaffolds for drug, cell and gene delivery used in different tissue engineering applications

\begin{tabular}{|c|c|c|c|c|c|}
\hline $\begin{array}{l}\text { Polymer(s)/carrier/ } \\
\text { scaffold structure }\end{array}$ & TE application & Active biomolecule & $\begin{array}{l}\text { Encapsulated/seeded cell type } \\
\text { (source) }\end{array}$ & Animal model & References \\
\hline Collagen/hydroxylapatite & Bone & NGF & - & Calvaria defects & [19] \\
\hline Collagen sponge & Cartilage & $\mathrm{bFGF}$ & Chondrocytes & $\begin{array}{l}\text { Nude mice subcutaneous } \\
\text { implantation }\end{array}$ & {$[20]$} \\
\hline Collagen gel & Bone/cartilage & BMP-2 gene & Bone marrow stromal cells & Mouse femoral muscle & {$[21]$} \\
\hline Collagen gel & Skin & $\begin{array}{l}\text { PDGF-A gene } \\
\text { PDGF-B gene }\end{array}$ & - & $\begin{array}{l}\text { Rabbit dermal ulcer } \\
\text { Swine dermal wound }\end{array}$ & {$[22]$} \\
\hline Collagen gel & Vascularization & VEGF & - & Chorioallantoic membrane & {$[23]$} \\
\hline $\begin{array}{l}\text { Collagen/heparan } \\
\text { sulfate matrix }\end{array}$ & Vascularization & bFGF & - & Rat & {$[24]$} \\
\hline $\begin{array}{l}\text { Collagen gel with } \\
\text { gelatin microspheres }\end{array}$ & Adipose & FGF-2 & - & Mouse groin & {$[25]$} \\
\hline Collagen-agarose beads & Not defined & - & Adults mesenchymal stem cells & - & {$[26]$} \\
\hline Collagen sponge & Bone & - & $\begin{array}{l}\text { Alveolar osteoblasts } \\
\text { gingival fibroblasts }\end{array}$ & $\begin{array}{l}\text { Critical-size defect in } \\
\text { mouse skull }\end{array}$ & {$[27]$} \\
\hline $\begin{array}{l}\text { Collagen electrospun } \\
\text { nanofibers }\end{array}$ & Bone & - & $\begin{array}{l}\text { Bone marrow-derived } \\
\text { mesenchymal stem cells (adult) }\end{array}$ & - & {$[28]$} \\
\hline $\begin{array}{l}\text { Collagen sponge } \\
\text { and hydrogel }\end{array}$ & Intervertebral disc & - & Human intervertebral disc cells & - & {$[29,30]$} \\
\hline Collagen sponge & Tooth & - & Porcine third molar cells & $\begin{array}{l}\text { Omentum of } \\
\text { immunocompromised rats }\end{array}$ & {$[31]$} \\
\hline Collagen sponge & Cartilage & - & Chondrocytes (autologous) & Sheep chondral defects & {$[32]$} \\
\hline Collagen membrane & Cartilage & - & Chondrocytes & $\begin{array}{l}\text { Medial femoral condyle of } \\
\text { New Zealand rabbits }\end{array}$ & {$[33]$} \\
\hline Collagen sponge & Adipose & - & Preadipocytes (human) & $\begin{array}{l}\text { Nude mice subcutaneous } \\
\text { implantation }\end{array}$ & {$[34]$} \\
\hline Collagen-GAG scaffold & Cardiovascular & - & $\begin{array}{l}\text { Bone marrow-derived mesenchymal } \\
\text { stem cells }\end{array}$ & Rat myocardial infarction & {$[35]$} \\
\hline Collagen scaffold (fleece) & Genito-urinary tract & - & Smooth muscle cells (human) & $\begin{array}{l}\text { Nude mice subcutaneous } \\
\text { implantation }\end{array}$ & {$[36]$} \\
\hline Collagen vitrigel & Renal glomerular tissue & - & $\begin{array}{l}\text { Glomerular mesangial cells, } \\
\text { Epithelial cells }\end{array}$ & - & {$[37]$} \\
\hline
\end{tabular}

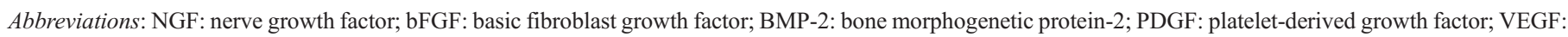
vascular endothelial growth factor; FGF-2: fibroblast growth factor-2; GAG: glycosaminoglycans.

Compiled from references [19-37].

\subsection{Gelatin}

Gelatin is a natural polymer that is derived from collagen, and is commonly used for pharmaceutical and medical applications because of its biodegradability and biocompatibility in physiological environments as reviewed by Tabata and Mikos $[38,39]$. These characteristics have contributed to gelatin's safety as a component in drug formulations or as a sealant for vascular prostheses [40]. Moreover, gelatin has relatively low antigenicity because of being denatured in contrast to collagen which is known to have antigenicity due to its animal origin. Gelatin contains a large number of glycine, proline and 4-hydroxyproline residues.

Gelatin is a denatured protein obtained by acid and alkaline processing of collagen. As a result, two different types of gelatin can be produced depending on the method in which collagen is pre-treated, prior to the extraction process [40]. This pre-treatment affects also the electrical nature of collagen, producing gelatin with different isoelectric points. The alkaline process targets the amide groups of asparagine and glutamine and hydrolyses them into carboxyl groups, thus converting many of these residues to aspartate and glutamate. In contrast, acidic pretreatment does little to affect the amide groups present. The result is that gelatin processed with an alkaline pre-treatment is electrically different from acidic-processed gelatin. This is due to hydrolysis of amide groups of collagen yields gelatin with a higher density of carboxyl groups present in the alkaline processed gelatin rendering it negatively charge and lowering its isoelectric point [38]. In contrast, the electrostatic nature of collagen is hardly modified through the acid process because of a less invasive reaction to amide groups of collagen. As a result, the isoelectric point of gelatin that is obtained with the acid process will remain similar to that of collagen [39]. By utilizing this technique, manufacturers now offer gelatin in a variety of isoelectric point values, being the most used the basic gelatin with an isoelectric point of 9.0 and the acidic gelatin with an isoelectric point of 5.0.

It is well accepted that a positively or negatively charged polyelectrolyte electrostatically interacts with an oppositely charged molecule to form a polyion complex [38]. The different processing conditions of gelatin allows for flexibility in terms of enabling polyion complexation of a gelatin carrier with either positively or negatively charged biomolecules. It is theoretically possible for gelatin to form polyion complexes with any type of charged biomolecules, although the strength of the interaction depends on the type of biomolecules used. If the 
biomolecule to be released is acidic, basic gelatin with an isoelectric point of 9.0 is preferable as a matrix, while acidic gelatin with an isoelectric point of 5.0 should be applicable to the control release of a basic protein. Both gelatins are insoluble in water to prepare a hydrogel through chemical crosslinking, for instance, with water-soluble carbodiimides and glutaraldehyde [39]. The gelatin hydrogels forming polyion complexes with proteins will facilitate the release of biologically active proteins. Generally, the release is controlled by matrix degradation [39] and therefore the time period for biomolecule release can be regulated by tailoring the hydrogel degradation. The biodegradable hydrogel matrices are prepared by chemical crosslinking of acidic or basic gelatin and are enzymatically degraded in the body with time. The degradation is controllable by changing the extent of crosslinking, which, in turn, produces hydrogels with different water contents [41]. In addition, as already referred, depending on the manufacturing method, variations in the electrical and physical properties of gelatinbased systems can be achieved. It is this flexibility in processing that has allowed gelatin-based systems to find several applications in fields ranging from tissue engineering to drug delivery and gene therapy.

The properties of gelatin as a typical rigid-chain high molecular weight compound are in many issues analogous to those of rigid-chain synthetic polymers [42]. Gelatin exhibits essentially the same common properties typical of polymeric substances, which is not the case with native collagen. Thus, in a similar way to linear-chain synthetic polymers, in aqueous solutions gelatin macromolecules assume, at elevated temperatures, the conformation of a statistical coil [42]. Under specific conditions, such as temperature, solvent or $\mathrm{pH}$, gelatin macromolecules present sufficient flexibility to realize a variety of conformations. This makes it possible to vary also all the gelatin characteristics dependent on its molecular structure. Besides, gelatin, similar to synthetic high polymers, shows a rather wide molecular weight distribution [42]. Structural diversity of gelatin chain units determines the specific features of gelatin properties. Most synthetic polymers show no such features that are typical of most biopolymers, such as the presence of both acidic and basic functional groups in the gelatin macromolecules.

Due to its promising properties, safety and mainly to the possibility of polyion complexation, gelatin is been used in drug delivery for tissue engineering applications targeting several tissues as we try to summarize in Table 2. Targeted tissues include bone, cartilage and skin, but others such as adipose tissue have applied gelatin as carrier to delivery an active biomolecule to improve the temporary cell functions. Due to its easy processability and gelation properties, gelatin as been manufactured in a range of shapes including sponges and injectable hydrogels, but definitively the most used carriers are gelatin microspheres which normally are incorporated in a second scaffold such as a hydrogel.

One of the most common strategies using gelatin microspheres is the encapsulation of biomolecules or cells in the microspheres with further incorporation of those in a second matrix. The group of Mikos [44-47,54,55] together with Tabata vast work with gelatin $[49,50,53]$ has been commonly using this strategy to incorporate a single biomolecule such as TGF- $\beta 1$ $[44,45]$, or in combination with IGF-1 for dual release [46] as well as the encapsulation of marrow stromal osteoblasts in the surface of the gelatin microspheres $[54,55]$. The results from these studies show the efficacy and safety of using gelatin based microspheres as carriers for tissue engineering applications. Besides the incorporation of growth factors and cells, the incorporation of cell adhesion proteins and peptides is also a strategy to be implemented to achieve a successful tissue engineering approach. Ito et al. [51] present a biodegradable gelatin hydrogels prepared through crosslinking of gelatin with transglutaminase (TGase) with fibronectin, vitronectin and RGD peptides (RGDLLQ and RGDLLG) incorporated to be applied as artificial skin or for bone and cartilage tissue engineering. NIH/3T3 fibroblasts were then added into the aqueous solution of gelatin to be part of the construct. Vitronectin and fibronectin can bind with gelatin by the action of TGase and as a cell adhesion factors it is expected to increase the cell growth. In fact, this study has shown that the gelatin matrices incorporating the cell adhesion factors such as vitronectin, fibronectin and RGD peptides by the action of TGase enhanced cell proliferation. Using gelatin carriers for cell delivery as shown to be also a promising technology for tissue engineering applications. Several examples include bovine and human chondrocytes [47,56], mesenchymal stem cells [57,58] and human preadipocytes [53] as described in Table 2. The strategies range the co-implantation of loaded microspheres [53] to the incorporation of the cells into porous scaffolds [57] and, in general, the in vivo results shown the higher efficiency of using gelatin carriers-based technology.

There are several commercially available gelatin based carriers for drug delivery that are being applied in tissue engineering applications $[48,56,57]$. The most commonly used ones are Gelfoam ${ }^{\circledR}$ commercialized now by Pfizer in USA (former Pharmacia and Upjohn) which is an absorbable gelatin sponge being also available in the powder form by milling the gelatin sponges. Gelfoam ${ }^{\circledR}$ is a sterile and workable surgical sponge prepared from specially treated and purified gelatin solution and it is used as a hemostatic device. Pfizer has also a commercially available Gelfilm ${ }^{\circledR}$ that is an absorbable gelatin film designed for use as an absorbable gelatin implant in neurosurgery and thoracic and ocular surgery. Surgifoam ${ }^{\circledR}$ is another commercially available porous, absorbable gelatin disks. This product is distributed by Ethicon Inc. in USA. CultiSpher- $\mathrm{G}^{\circledR}$ is another gelatin based product marketed by Percell Biolytica AB in Sweden which is a macroporous gelatin microcarrier beads used as microcarrier cell culture. CultiSpher$\mathrm{S}^{\circledR}$ is the same product with a different crosslinking procedure conferring a higher thermal and mechanical stability.

\subsection{Silk fibroin}

Silk is generally defined as protein polymers that are spun into fibers by some lepidoptera larvae such as silkworms, spiders, scorpions, mites and flies [59]. Spider silk is an intriguing biomaterial that is lightweight, extremely strong and 
Table 2

Gelatin-based matrices/scaffolds for drug and cell delivery used in different tissue engineering applications

\begin{tabular}{|c|c|c|c|c|c|}
\hline $\begin{array}{l}\text { Polymer(s)/carrier/ } \\
\text { scaffold structure }\end{array}$ & TE application & Active biomolecule & $\begin{array}{l}\text { Encapsulated/seeded cell type } \\
\text { (source) }\end{array}$ & Animal model & References \\
\hline Gelatin (hydrogel) & Bone & $\mathrm{bFGF}$ & - & $\begin{array}{l}\text { Nude mice } \\
\text { subcutaneous implantation }\end{array}$ & {$[38]$} \\
\hline $\begin{array}{l}\text { Gelatin-siloxane } \\
\text { (porous freeze-dried scaffolds) }\end{array}$ & Bone & $\begin{array}{l}\text { Gentamicin } \\
\text { sulfate }\end{array}$ & $\begin{array}{l}\text { Osteoblast-like MC3T3-E1 } \\
\text { cell line }\end{array}$ & - & {$[43]$} \\
\hline $\begin{array}{l}\text { Gelatin microspheres encapsulated } \\
\text { in a hydrogel injectable matrix }\end{array}$ & Cartilage & TGF- $\beta 1$ & - & - & {$[44,45]$} \\
\hline $\begin{array}{l}\text { Gelatin microspheres encapsulated } \\
\text { in a hydrogel injectable matrix }\end{array}$ & Cartilage & $\begin{array}{l}\text { TGF- } \beta 1 \text { and } \\
\text { IGF-I }\end{array}$ & - & - & {$[46]$} \\
\hline $\begin{array}{l}\text { Gelatin microspheres encapsulated } \\
\text { in a hydrogel injectable matrix }\end{array}$ & Cartilage & TGF- $\beta 1$ & Bovine chondrocytes & - & {$[47]$} \\
\hline Porous gelatin disks $\left(\right.$ Surgifoam ${ }^{\mathbb{R}}$ ) & Cartilage & TGF- $\beta 1$ (medium) & $\begin{array}{l}\text { Human adipose-derived } \\
\text { adult stem cells }\end{array}$ & - & {$[48]$} \\
\hline Gelatin sponge & $\begin{array}{l}\text { Bone } \\
\text { Cartilage }\end{array}$ & BMP-2 & - & $\begin{array}{l}\text { Tracheal cartilage rings } \\
\text { in canine cervix }\end{array}$ & {$[49,50]$} \\
\hline $\begin{array}{l}\text { Transglutaminase crosslinked } \\
\text { gelatin (hydrogel) }\end{array}$ & $\begin{array}{l}\text { Bone } \\
\text { Cartilage } \\
\text { Artificial skin }\end{array}$ & $\begin{array}{l}\text { Vitronectin/fibronectin } \\
\text { RGD peptides }\end{array}$ & $\begin{array}{l}\text { Fibroblasts-like NIH/3T3 } \\
\text { cell line }\end{array}$ & - & {$[51]$} \\
\hline $\begin{array}{l}\text { Gelatin microspheres incorporated } \\
\text { in collagen gel }\end{array}$ & Adipose & FGF-2 & - & $\begin{array}{l}\text { Tissue engineering chambers } \\
\text { in mouse groins }\end{array}$ & {$[25]$} \\
\hline $\begin{array}{l}\text { Photocured styrenated } \\
\text { gelatin microspheres }\end{array}$ & Adipose & bFGF, insulin, IGF-I & - & $\begin{array}{l}\text { Nude mice } \\
\text { subcutaneous implantation }\end{array}$ & {$[52]$} \\
\hline $\begin{array}{l}\text { Gelatin microspheres incorporated } \\
\text { in a collagen sponge }\end{array}$ & Adipose & bFGF & Human preadipocytes & $\begin{array}{l}\text { Nude mice } \\
\text { subcutaneous implantation }\end{array}$ & {$[53]$} \\
\hline $\begin{array}{l}\text { Gelatin microspheres encapsulated } \\
\text { in an hydrogel matrix }\end{array}$ & Bone & - & Rat marrow stromal osteoblasts & - & {$[54,55]$} \\
\hline $\begin{array}{l}\text { Macroporous gelatin microcarriers } \\
\text { beads }\left(\text { CultiSpher } \mathrm{G}^{\circledR}\right)\end{array}$ & Cartilage & - & Human nasal chondrocytes & $\begin{array}{l}\text { Nude mice } \\
\text { subcutaneous implantation }\end{array}$ & {$[56]$} \\
\hline Porous gelatin sponge $\left(\right.$ Gelfoam $\left.^{\circledR}\right)$ & Cartilage & - & $\begin{array}{l}\text { Adult human mesenchymal } \\
\text { stem cells }\end{array}$ & $\begin{array}{l}\text { Osteochondral defect in the } \\
\text { rabbit femoral condyle }\end{array}$ & {$[57]$} \\
\hline $\begin{array}{l}\text { Gelatin and chemically modified } \\
\text { hyaluronic acid injectable hydrogel }\end{array}$ & Osteochondral & - & $\begin{array}{l}\text { Rabbit bone marrow-derived } \\
\text { mesenchymal stem cells }\end{array}$ & $\begin{array}{l}\text { Rabbit osteochondral } \\
\text { knee joint }\end{array}$ & {$[58]$} \\
\hline
\end{tabular}

Abbreviations: bFGF: basic fibroblast growth factor; TGF- $\beta 1$ : transforming growth factor- $\beta 1$; BMP-2: bone morphogenetic protein-2; RGD: Arg-Gly-Asp peptides; FGF-2: fibroblast growth factor-2; IGF-I: insulin growth factor-1.

Compiled from references $[25,38,43-58]$.

elastic, and exhibits mechanical properties comparable to the best synthetic fibers produced by modern technology [60]. Spider silk is spun near ambient temperatures and pressures using water as the solvent, which gives rise to an environmentally safe, biodegradable material [60]. However, it is not possible to maintain domesticated spiders to produce massive amounts of silk. Therefore, the attention was turned to silk fibroin, a mass-producible natural polymer produced by silkworms, commonly used as a textile fiber. In the medical field, silk has long been used for surgical sutures [61].

The silkworm Bombyx mori produces silk to weave its cocoon, and its major components are fibroin and sericin. Fibroin is a fibrous protein constituting the core of silk, while sericin is a glue-like protein surrounding fibroin. Fibroin is composed of fibroin H-chain (FH), fibroin L-chain (FL), and fibrohexamerin at a molar rate of 6:6:1 [62]. Silks are attractive biomaterials for tissue engineering, because of their biocompatibility [59,63], slow degradability [64] and excellent mechanical properties. Some examples are shown in Table 3. Degradable silk is a mechanically robust biomaterial that offers a wide range of mechanical and functional properties for biomedical applications including drug delivery $[65,66]$.
Besides the applications that can be found in Table 3, a very interesting approach is the one described by Hino and coworkers [75] where the authors aimed to prepare a novel type of bFGF delivery system using fibroin as a scaffold. They generated transgenic silkworms that bore a gene encoding FL fused with bFGF (FL/bFGF). The transgenic silkworms spun cocoons whose fibroin layers were composed of both inherent genederived natural fibroin $(\mathrm{nF})$ and the recombinant $\mathrm{FL} / \mathrm{bFGF}$, $\mathrm{r}(\mathrm{FL} / \mathrm{bFGF})$. When human umbilical vein endothelial cells (HUVECs) were seeded in the scaffold, they were able to grow in the refolded $\mathrm{r}(\mathrm{FL} / \mathrm{bFGF}) \mathrm{nF}$-containing culture media, showing that bFGF in $\mathrm{r}(\mathrm{FL} / \mathrm{bFGF})$ was biologically active [75]. $\mathrm{r}$ (FL/ bFGF)nF immobilized on a culture dish also supported the growth of HUVECs in bFGF-free media, suggesting the usefulness of $\mathrm{r}(\mathrm{FL} / \mathrm{bFGF}) \mathrm{nF}$ as a new biomaterial for tissue engineering [75].

\subsection{Fibrin}

Fibrin and fibrinogen have a well-established application in research in tissue engineering due to their innate ability to induce improved cellular interaction and subsequent scaffold 
Table 3

Silk fibroin-based matrices/scaffolds for drug and cell delivery used in different tissue engineering applications

\begin{tabular}{|c|c|c|c|c|c|}
\hline $\begin{array}{l}\text { Polymer(s)/carrier/ } \\
\text { scaffold structure }\end{array}$ & TE application & Active biomolecule & $\begin{array}{l}\text { Encapsulated/seeded cell type } \\
\text { (source) }\end{array}$ & Animal model & References \\
\hline Silk fibroin fibre scaffolds & Bone & BMP-2 & $\begin{array}{l}\text { Bone marrow-derived mesenchymal } \\
\text { stem cells }\end{array}$ & - & [67] \\
\hline Silk fibroin non-woven net & Angiogenesis & - & Endothelial cells & - & {$[69,70]$} \\
\hline Silk fibroin porous scaffolds & Cartilage & - & Mesenchymal stem cells & - & [71] \\
\hline $\begin{array}{l}\text { Silk fibroin electrospun } \\
\text { fiber scaffolds }\end{array}$ & Wound dressing & - & Keratinocytes and fibroblasts & - & {$[72]$} \\
\hline Silk fibroin multi-fiber matrix & Anterior crucial ligament & - & $\begin{array}{l}\text { Bone marrow-derived mesenchymal } \\
\text { stem cells }\end{array}$ & - & [74] \\
\hline
\end{tabular}

Abbreviations: BMP-2: bone morphogenetic protein-2.

Compiled from references [67-74].

remodelling compared to synthetic scaffolds. Furthermore, due to its biochemical characteristics, mainly in cellular interactions, fibrin-based materials also found applications in the field of drug delivery with special focus in cell delivery.

Fibrin is a protein matrix produced from fibrinogen, which can be autologously harvested from the patient [76], providing an immunocompatible carrier for delivery of active biomolecules, specially cells. Polymerized fibrin is a major component of blood clots and plays a vital role in the subsequent wound healing response [77]. In vivo, formation of fibrin clots is initiated by vascular injury, which causes the release of the enzyme thrombin, a serine protease that activates many constituents of the coagulation cascade [78]. Thrombin cleaves peptide fragments from the soluble plasma protein fibrinogen, yielding insoluble fibrin peptides that aggregate to form fibrils [79]. A fibrin meshwork is formed, which entraps platelets and other blood-borne components to create a clot that is stabilized through crosslinking by the transglutaminase Factor XIII $[79,80]$. In addition, fibrin naturally contains sites for cell binding, and therefore has been investigated as a substrate for cell adhesion, spreading, migration and proliferation [81].

Fibrin glue is a biological adhesives also used in surgery (abdominal, thoracic, vascular, oral, endoscopic) due to its haemostatic, chemotactic and mitogenic properties [82]. Fibrin glue mimics the last step of the in vivo coagulation cascade through activation of fibrinogen by thrombin, resulting in a clot of fibrin with adhesive properties [83]. Fibrinogen is converted into a monomeric form of fibrin by thrombin which forms the fibrin clot. Mechanisms of fibrin production and clot assembly have been elucidated primarily from studies in which a specific amount of thrombin is added to purified fibrinogen as clearly described in [79]. The concentration of fibrinogen is 20-40 times higher in fibrin sealant products than in body fluid. The formation of the fibrin clot and the physiological properties are then enhanced. This concentration also determines the properties of the fibrin clot (adhesive strength, rate of formation, network conformation, permeability and fiber diameter) and modifications to concentrations can be made to allow the fibrin glue to fit the application [82]. A number of variables other than the concentration of thrombin and fibrinogen can also influence the structure of a fibrin gel, including the local $\mathrm{pH}$, ionic strength, and concentrations of calcium [79]. The relative influence of fibrinogen and thrombin concentration in the final gel structure and properties when comparing with each other is still not clear. There are works showing that fibrinogen concentration is more critical to the final properties $[84,85]$ as well as works showing that thrombin concentrations lead to more modifications in the structure of the clot than modifications to fibrinogen concentrations [78,83]. Extremely low concentrations of thrombin $(<1 \mathrm{nM},<0.1 \mathrm{U} / \mathrm{mL})$ are sufficient to cleave fibrino-peptides and catalyze fibrin polymerization [79]. These low thrombin concentrations produce fibrin clots that are turbid and composed of thick, loosely-woven fibrin strands. Higher concentrations of thrombin produce fibrin clots that are composed of relatively thinner, more tightly-packed fibrin strands. There are a several works trying to stabilizing and modulate the properties of the fibrin gels with thrombin in order to get more stable gels $[78,79]$. However, this important fibrin characteristic of increasing instability and solubility over time in vitro and in vivo is due to fibrinolysis which could be an advantage for in wound sealing or other surgical applications as well as for cell and growth factor delivery. Fibrin provides a material that can be rapidly invaded, remodeled and replaced by cell-associated proteolytic activity [80]. Moreover, due to its biomimetic and physical properties it is also widely used as a cell carrier to many cell types, such as keratinocytes [86], urothelium cells [86], tracheal epithelial cells [86], murine embryonic stem cells [87] mesenchymal progenitor cells [88] and also very used to encapsulate chondrocytes for cartilage tissue engineering [89-91]. But rapid degradation can represent a problem for use as a shape-specific scaffold in tissue engineering, therefore optimizing fibrin composition is a fundamental approach to obtain a scaffold system providing optimal shape stability and integrity for specific applications in tissue engineering. In spite of this factor, fibrin as a carrier of active biomolecules and particularly as support for cell delivery as been applied to the tissue engineering field as presented in Table 4 . The table summarizes the polymer and carriers shape used in the system, the aimed tissue engineering application, the biologically active biomolecule to be delivered, the source of 
Table 4

Fibrin-based matrices/scaffolds for drug and cell delivery described for different tissue engineering applications

\begin{tabular}{|c|c|c|c|c|c|}
\hline $\begin{array}{l}\text { Polymer(s)/carrier/ } \\
\text { scaffold structure }\end{array}$ & TE application & Active biomolecule & $\begin{array}{l}\text { Encapsulated/seeded cell type } \\
\text { (source) }\end{array}$ & Animal model & References \\
\hline Fibrin films & Not defined & FGF-2 (patterning) & $\begin{array}{l}\text { Human MG-63 } \\
\text { "preosteoblastic" } \\
\text { osteosarcoma cells }\end{array}$ & - & {$[92]$} \\
\hline $\begin{array}{l}\text { Fibrin gel }\left(\text { Tissee }^{\circledR}\right) \text { combined } \\
\text { with plotted PCL/TCP }\end{array}$ & Bone & rhBMP-2 & Human osteoblasts & - & [93] \\
\hline Fibrin gel & Bone & ngl BMP-2 & - & $\begin{array}{l}\text { Critical-size defects in } \\
\text { the rat calvarium and } \\
\text { inter-carpal fusion in dogs }\end{array}$ & {$[80]$} \\
\hline $\begin{array}{l}\text { Fibrin gel containing heparin- } \\
\text { conjugated nanospheres }\end{array}$ & Vascularization & bFGF & $\begin{array}{l}\text { Human umbilical vein } \\
\text { endothelial cells }\end{array}$ & Mouse limb ischemia & {$[94,95]$} \\
\hline Fibrin gel & Vascularization & VEGF variants & $\begin{array}{l}\text { Human umbilical vein } \\
\text { endothelial cells }\end{array}$ & - & {$[81]$} \\
\hline Fibrin gel & $\begin{array}{l}\text { Skin } \\
\text { Cardiovascular }\end{array}$ & $\begin{array}{l}\text { TGF- } \beta 1 \text {, } \\
\text { insulin and plasmin } \\
\text { (in the culture medium) }\end{array}$ & $\begin{array}{l}\text { Human foreskin } \\
\text { fibroblasts cell line }\end{array}$ & - & {$[77]$} \\
\hline Fibrin gel and beads & Spinal cord injury & NT-3 & $\begin{array}{l}\text { Chick dorsal root } \\
\text { ganglia cell culture }\end{array}$ & $\begin{array}{l}\text { Rat suction ablation } \\
\text { spinal cord injury }\end{array}$ & {$[96,97]$} \\
\hline Fibrin gel & $\begin{array}{l}\text { Peripheral nerve } \\
\text { regeneration }\end{array}$ & $\begin{array}{l}\text { bFGF, VEGF, } \\
\beta-N G F, N T-3\end{array}$ & $\begin{array}{l}\text { Chick dorsal root } \\
\text { ganglia cell culture }\end{array}$ & Rat sciatic nerve defect & {$[98-100]$} \\
\hline Fibrin gel & Intervertebral disc & - & $\begin{array}{l}\text { Human intervertebral } \\
\text { disc cells }\end{array}$ & - & {$[30]$} \\
\hline Fibrin-collagen gel & Cartilage & - & Embryonic chondrogenic cells & - & [91] \\
\hline Fibrin gel & Cartilage & - & Bovine articular chondrocytes & - & {$[89,90,101]$} \\
\hline $\begin{array}{c}\text { Fibrin gel in a PGA } \\
\text { non-woven mesh }\end{array}$ & Cartilage & - & Pig chondrocytes & - & {$[102]$} \\
\hline Porous fibrin gel & Cartilage & - & Human articular chondrocytes & - & {$[103]$} \\
\hline $\begin{array}{l}\text { Fibrin glue (Tisseel) combined } \\
\text { with plotted medical-grade PCL }\end{array}$ & Osteochondral & - & $\begin{array}{l}\text { Rabbit bone marrow-derived } \\
\text { mesenchymal cells }\end{array}$ & $\begin{array}{l}\text { Rabbit medial } \\
\text { femoral condyle }\end{array}$ & {$[104]$} \\
\hline Fibrin scaffold & Spinal cord injury & - & Murine embryonic stem cells & - & [87] \\
\hline Fibrin tubes (autologous) & Vascularization & - & Outgrowth endothelial cells & - & {$[76]$} \\
\hline Fibrin gel & Vascularization & - & Rat aortic smooth muscle cells & - & {$[78]$} \\
\hline Fibrin gel in a fiber-based scaffold & Cardiovascular & - & $\begin{array}{l}\text { Human venous } \\
\text { myofibroblasts }\end{array}$ & - & {$[105]$} \\
\hline
\end{tabular}

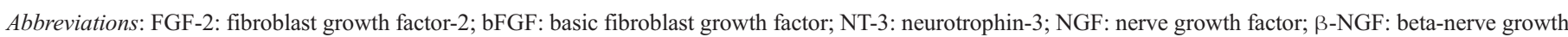

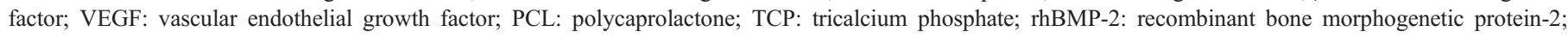
nglBMP-2: non-glycosylated form of bone morphogenetic protein-2; PGA: polyglycolic acid; TGF- $\beta 1$ : transforming growth factor-beta 1.

Compiled from references [30,76-78,80,81,87,89-105].

the cell used to test the developed systems in vitro or the cell type incorporated in the system in the last part of the table. When applicable the used animal model is also referred.

One interesting work is presented by Aper et al. [76] where autologous blood vessels are engineered from peripheral blood sample. The objective is the development of a bioartificial vascular graft by means of an autologous scaffold material seeded with endothelial progenitor cells separated from the peripheral blood of a single donor. With regard to a later clinical application, the scaffold material should be generated easily without the need for surgical procedure to harvest it from the body of the later recipient [76].

Fibrinogen and thrombin from different sources including human are commercially available in the usual chemical suppliers and normally are used to produce the fibrin gel in research works. Nevertheless, there is an already available industrially produced homologous fibrin sealant. The most used one is Tisseel $\mathrm{VH}^{\circledR}$ commercialized by Baxter, USA and consists of a two-component fibrin biomatrix with highly concentrated human fibrinogen. Moreover, it is possible also to produce fibrin gel from a blood sample [76]. There are several commercially available devices that allow for this. An example is the CryoSeal ${ }^{\circledR}$ Fibrin Sealant System manufactured by Thermogenesis in USA which enables the production of autologous fibrin sealant components from a single unit of a patient's blood plasma in about $60 \mathrm{~min}$. Another example is Vivostat ${ }^{\circledR}$ System commercialized by Vivolution, Denmark which is an automated system for the on-site preparation and application of patient-derived fibrin sealant or platelet-rich fibrin. There is a published study [106] which compares the properties in different aspects concluding that there are clear differences between the commercially available ways to obtain fibrin gel.

\subsection{Other protein-based polymers}

There are other very interesting and attractive protein-origin polymers namely elastin and soybean that have been applied in some extent in the tissue engineering applications. We have decided to include them just as a general overview due to the 
limited application as drug delivery carriers or cell carriers in the tissue engineering field but justifying their use in tissue engineering.

Elastin is the dominant extracellular matrix protein deposited in the arterial wall and can contribute up to $50 \%$ of its dry weight. The protein product of the elastin gene is synthesized by vascular smooth muscle cells and secreted as a tropoelastin monomer that is soluble, non-glycosylated and highly hydrophobic [107]. Elastin is the responsible component conferring elasticity, preventing dynamic tissue creep by stretching under load and recoiling to their original configurations after the load is released. In addition to the mechanical responsiveness, elastin is a potent autocrine regulator of vascular smooth muscle cells activity and this regulation is important for preventing fibrocellular pathology [6]. Given elastin importance in governing the mechanical properties of native vessels and their role in vascular smooth muscle cells activity, the development of processable elastin-based biomaterials could advance the design of biofunctional blood vessel replacements, in vascular tissue engineering (where the main application is found) or achieving vascularization in bone regeneration. Such elastin-based biomaterials may not need to initially resemble the precise structural organization of native elastin, but could serve as templates for cellular remodeling and reorganization, being a critical issue in the referred applications as reviewed by Patel et al. [6]. Nevertheless, the development of elastin-based biomaterials is still an exploitable area for other application rather than vascular tissue engineering. Examples of applications in this field are proposed by Buttafoco et al. [108] where the addition of polyethylene oxide and sodium chloride was necessary to spin continuous and homogeneous elastin fibers by an electrospinning method. The formation of a confluent multi-layer of smooth muscle cells, growing on top of each nanofiber meshes was observed by means of histology [108]. Other application is proposed by $\mathrm{Lu}$ et al. [107] the attempt to create porous structures for cell repopulation removing selectively matrix components from decellularized porcine aorta to obtain two types of scaffolds, namely elastin and collagen scaffolds. Fibroblasts were used for cell culture and they infiltrated about $120 \mu \mathrm{m}$ into elastin scaffolds and about $40 \mu \mathrm{m}$ into collagen scaffolds after 4 weeks of rotary cell culture. These results indicated that the developed novel aortic elastin matrices have the potential to serve as scaffolds for cardiovascular tissue engineering. Moreover, Leach et al. [109] propose a simple synthesis technique for creating elastin-based biomaterials. They present a versatile system of two commercially available and water-soluble components: $\alpha$-elastin (a well-characterized elastin digest) and ethylene glycol diglycidylether (a diepoxy crosslinker) to develop a pHdependent crosslinking scheme to yield insoluble $\alpha$-elastin biomaterials. Studies of vascular smooth muscle cells attachment and proliferation were used to confirm the predicted cell response to $\alpha$-elastin substrates [109]. The results suggest that crosslinked $\alpha$-elastin could provide a platform for complex composite materials with both mechanical and bioactive properties that closely mimic native vascular tissue.

Recombinant protein technologies have allowed the synthesis of well-defined elastin-derived polypeptides (ELPs), which have driven insightful structure-function studies of tropoelastin (the soluble precursor of crosslinked elastin) and have gained more attention. ELPs are artificial biopolymers composed of the pentapeptide repeat Val-Pro-Gly-Xaa-Gly (VPGXG), which is derived from the hydrophobic domain of tropoelastin. At low temperatures, ELPs are soluble in aqueous solution, but as the solution temperature is raised, they become insoluble and aggregate at a critical temperature, termed the 'inverse transition temperature' $(\mathrm{Tt})$, a phenomenon similar to the lower critical solution temperature transition [5]. This process is typically reversible so that subsequent cooling of the solution below the $\mathrm{Tt}$ results in the re-solubilization of the ELP. This transition has become the key issue in the development of new peptide-based polymers as molecular machines and materials. The basic structure of ELPs is a repeating sequence originating in the repeating sequences found in the mammalian elastic protein, elastin [2]. Some of their main characteristics of these ELPs are derived from the natural protein they are based on. For example, the crosslinked matrices of these polymers retain most of the striking mechanical properties of elastin, i.e. almost ideal elasticity with Young's modulus, elongation at break, etc. in the range of the natural elastin and outstanding resistance to fatigue [5]. ELPs have found application in the drug delivery field due to the ability to synthesize them with a precise molecular weight and low poly-dispersity, their potential biocompatibility and controlled degradation.

In the tissue engineering field, the biodegradation and biocompatibility of ELPs are suitable for preparing bulk implants and/or injectables. These implants can hold cells, providing a substrate for tissue engineering. In one approach, Betre et al. [110] investigated the potential of a genetically engineered ELPs to promote the chondrocytic differentiation of human adipose derived adult stem cells without exogenous chondrogenic supplements. The results demonstrate that ELPs can provide the appropriate physical and biochemical environment to maintain chondrocyte differentiation and support cartilage matrix synthesis in vitro and suggest the potential utility of ELPs to serve as a scaffold for cartilage repair. Moreover, the study suggests that ELPs can promote chondrogenesis for human adipose derived adult stem cells in the absence of exogenous TGF- $\beta 1$ and dexamethasone, especially under low oxygen tension conditions [110]. Finally the potential of ELPs to selfassemble into nanostructures in response to environmental cues, a nascent area of research, will lead to a host of new applications of these recombinant polymers.

Soybean, from the most cultivated plant in the world, is rich in proteins $(40-50 \%)$, lipids $(20-30 \%)$ and carbohydrates (26-30\%), and consequently the subject of extensive scientific research [111]. The soybean (USA and UK) or soya bean (UK) (from an annual plant, Glycine Max L. Merrill [112]) is a species of legume native that can be processed into three kinds of protein-rich products; soy flour, soy concentrate, and soy isolate which varies in protein content. Isolated soy protein (highly refined or purified form), the most concentrated source of soy protein by definition contains $90 \%$ protein on a dry weight basis, followed by soy concentrate (soybean without the water-soluble carbohydrates) at $70 \%$ protein and soy flour 
(made by grinding soybeans into a fine powder) at $50 \%$ protein on a dry weight basis. The major soy proteins (greater than $85 \%$ ) are glycinin, or $11 \mathrm{~S}$, and $\beta$-conglycinin, or $7 \mathrm{~S}$, which represent $34 \%$ and $27 \%$, respectively, of the proteins occurring in the isolate $[111,113]$. Soy protein is abundant, renewable, inexpensive and biodegradable, making it an attractive source of degradable materials for tissue engineering uses. Nevertheless, the application of soy-based polymers in this field is still very narrow, especially if one considers application for growth factor or cell delivery. The main field of soy application is by far the food industry and more recently as environment-friendly biodegradable 'green' alternatives for biolpolymers and composites for use in various applications including computer casings and electronic chip packaging [112]. However, soy is also expected to present a tailorable degradation profile [114] varying with the crosslinking degree which constitutes an advantage for drug delivery systems design. Furthermore to improve soy properties (namely mechanical, degradation, solubility and hydrophilicity) it is common to mix with other polymers such as dextran [115,116], chitosan [117], gelatin [118], carrageenan [119], and starch [116,120]. The use of soy-based polymers for drug delivery and tissue engineering applications is proposed by the group of Reis et al. [117,121-123] where soy-based thermoplastics and membranes are described and characterized as biomaterials and carriers for drug delivery applications.

\section{Polysaccharidic polymers}

\subsection{Introduction}

Polysaccharides are a class of biopolymers constituted by simple sugar monomers [124]. The monomers (monosaccharides) are linked together by $O$-glycosidic bonds that can be made to any of the hydroxyl groups of a monosaccharide, conferring polysaccharides the ability to form both linear and branched polymers. Differences in the monosaccharide composition, chain shapes and molecular weight dictate their physical properties including solubility, gelation and surface properties. These biological polymers can be obtained from different sources: microbial, animal and vegetal [125]. Several advantages can be derived from the use of these macromolecules. First of all, probably because of the chemical similarities with heparin, polysaccharides show good hemocompatibility properties. They are non-toxic, show interaction with living cells and, with few exceptions, have low costs in comparison with others biopolymers such as collagen $[125,126]$. These polysaccharidic polymers have been widely proposed as scaffold materials in tissue engineering applications as well as carriers for drug delivery systems as described in more detail in the following sections.

\subsection{Chitosan}

Chitosan is a cationic polymer obtained from chitin comprising copolymers of $\beta(1 \rightarrow 4)$-glucosamine and $N$-acetyl-Dglucosamine. Chitin is a natural polysaccharide found particularly in the shell of crustacean, cuticles of insects and cell walls of fungi and is the second most abundant polymerized carbon found in nature. Chitosan, the fully or partially deacetylated form of chitin, due to its properties as attracted much attention in the tissue engineering and drug delivery fields with a wide variety of applications ranging from skin, bone, cartilage and vascular grafts to substrates for mammalian cell culture. It has been proved to be biologically renewable, biodegradable, biocompatible, non-antigenic, non-toxic and biofunctional [127].

The term chitosan is used to describe a series of polymers of different degrees of deacetylation defined in terms of the percentage of primary amino groups in the polymer backbone and average molecular weights. The degree of deacetylation of typical commercial chitosan is usually between $70 \%$ and $95 \%$, and the molecular weight between 10 and $1000 \mathrm{kDa}$ [128]. The properties, biodegradability and biological role of chitosan are dependent on the relative proportions of $N$-acetyl-D-glucosamine and D-glucosamine residues [129]. In preparing chitosan, ground shells are deproteinated and demineralized by sequential treatment with alkali and acid, after which the extracted chitin is deacetylated to chitosan by alkaline hydrolysis at high temperature. Production of chitosan from these sources is inexpensive, easy and can provide additional control over chitosan final properties.

In addition, chitosan molecule has amino and hydroxyl groups which can be modified chemically providing a high chemical versatility and is metabolized by certain human enzymes, especially lysozyme being considered biodegradable. Chitosan is also a bioadhesive material. The adhesive properties of chitosan in a swollen state have been shown to persist well during repeated contacts of chitosan and the substrate [128] which implies that, in addition to the adhesion by hydration, many other mechanisms, such as hydrogen bonding and ionic interactions might also have be involved. Moreover, chitosan exhibits a pH-sensitive behavior as a weak poly-base due to the large quantities of amino groups on its chain. Chitosan dissolves easily at low $\mathrm{pH}$ while it is insoluble at higher $\mathrm{pH}$ ranges. The mechanism of $\mathrm{pH}$-sensitive swelling involves the protonation of amine groups of chitosan under low $\mathrm{pH}$ conditions. This property has held chitosan to be widely investigated as a delivery matrix. Crosslinking is often used to tailor chitosan-based materials properties. The most common crosslinkers used to crosslink chitosan are dialdehydes such as glyoxal [130] and glutaraldehyde [131]. The aldehyde groups form covalent imine bonds with the amino groups of chitosan due to the resonance established with adjacent double ethylinic bonds via a Schiff reaction [128]. Dialdehydes allow the crosslinking to happen by direct reaction in aqueous media and under mild conditions. Moreover, dihaldehydes such as glutaraldehyde stabilize the collagen structure, prevent tissue digestion by enzymes or bacteria and reduce the antigenicity of the material [132]. It also adds to retaining the biocompatibility of the polymer. Natural crosslinkers like genipin [133] are gaining wide acceptance for crosslinking chitosan.

Porous chitosan matrix may be suggested as a potential candidate as a bone regenerative material due to its proper biological and physical properties. Biological activity of chitosan on bone regeneration has been demonstrated in many 
reports [134,135]. However, chitosan has some limitations in inducing rapid bone regeneration at initial stages. Bone formation after implanting these matrices occurs over a long period (several months or years) [127]. Additional functions for chitosan materials are necessary to shorten bone forming period and improve their efficacy. Incorporation of active biomolecules such as growth factors has been used as a strategy which is highly beneficial for obtaining improved bone regeneration.

Concerning cartilage engineering, chitosan is structurally similar to glycosaminoglycans (GAGs) found in extracellular matrices as in native articular cartilage and are very important in playing a key role in modulating chondrocytes morphology, differentiation and function. This characteristic together with the ones previously described makes chitosan also an attractive natural-origin polymer to engineered cartilage. In addition, chitosan was found to enhance blood coagulation [136] accelerating wound healing $[137,138]$, thus it can act as an ideal wound dressing as it exhibits a positive charge, film-forming capacity, mild gelation characteristics and a strong tissueadhesive property. Research work indicates that chitosan enhances the functions of inflammatory cells such as polymorphonuclear leukocytes, macrophages and fibroblasts promoting granulation and organization [136]. Therefore, chitosan can be used for large open wounds [139]. A study showed that chitosan-treated wounds were epithelized when compared with wounds of the control group after the treatment [137,139].

Table 5 intends to summarize some relevant application of chitosan-based materials in the tissue engineering field and drug delivery aiming several tissues. The incorporation of a wide range of bioactive molecule highlights the potential of this natural origin to these applications, including gene delivery.

Some commercially available formats of chitosan include the geniaBeads ${ }^{\circledR}$ CN commercialize by Genialab in Germany which are hydrogel beads made from chitosan. Due to chitosan properties in wound healing, a commercially available product is HemCon ${ }^{\circledR}$ bandage from HemCon Medical Technologies Inc. in USA which is a chitosan bandage. This bandage can be applied with pressure to a severe external wound and in several minutes attracts blood cells (negatively charged surface) that merge with chitosan forming a blood clot. The bleeding stops and the bandage adhere tightly to the wound, so the person can be moved without more bleeding. Chitosan has also been marketed throughout the world as a component in non-medical products, as a fat binder in cholesterol-lowering and slimming formulations. It has been claimed that chitosan entraps lipids in the intestine due to its cationic nature.

Table 5

Chitosan-based matrices/scaffolds for drug, cell and gene delivery described for different tissue engineering applications

\begin{tabular}{|c|c|c|c|c|c|}
\hline $\begin{array}{l}\text { Polymer(s)/carrier/ } \\
\text { scaffold structure }\end{array}$ & TE application & Active biomolecule & $\begin{array}{l}\text { Encapsulated/seeded cell type } \\
\text { (source) }\end{array}$ & Animal model & References \\
\hline Chitosan-alginate fibers & Not defined & Dexamethasone, PDGF-BB & - & - & {$[140]$} \\
\hline Galactosylated chitosan coating & Not defined & EGF & Mouse hepatocytes & - & [141] \\
\hline $\begin{array}{l}\text { Chitosan granules in a TCP/ } \\
\text { chitosan hydrogel }\end{array}$ & Bone & PDGF & - & Rat femur defect & [142] \\
\hline Chitosan freeze-dried scaffolds & Bone & PDGF-BB & Rat calvarial osteoblasts & - & [135] \\
\hline Chitosan/collagen scaffolds & Periodontal bone & TGF- $\beta 1$ plasmid & $\begin{array}{l}\text { Human periodontal } \\
\text { ligament cells }\end{array}$ & $\begin{array}{l}\text { Nude mice } \\
\text { subcutaneous implantation }\end{array}$ & {$[143]$} \\
\hline Chitosan/coral scaffolds & Periodontal bone & PDGFB plasmid & $\begin{array}{l}\text { Human periodontal } \\
\text { ligament cells }\end{array}$ & $\begin{array}{l}\text { Nude mice } \\
\text { subcutaneous implantation }\end{array}$ & [144] \\
\hline Chitosan freeze-dried sponge & Periodontal bone & PDGF-BB & $\begin{array}{l}\text { Fetal rat calvarial } \\
\text { osteoblastic cells }\end{array}$ & Rat calvarial defect & {$[145]$} \\
\hline $\begin{array}{l}\text { Chitosan/gelatin } \\
\text { freeze-dried scaffolds }\end{array}$ & Cartilage & TGF- $\beta 1$ plasmid & Rabbit articular chondrocytes & - & [146] \\
\hline $\begin{array}{l}\text { Chitosan microspheres in chitosan } \\
\text { freeze-dried scaffolds }\end{array}$ & Cartilage & TGF- $\beta 1$ & Porcine articular chondrocytes & - & [147] \\
\hline $\begin{array}{l}\text { Chitosan microspheres in chondroitin } \\
\text { sulfate-collagen-chitosan } \\
\text { freeze-dried scaffolds }\end{array}$ & Cartilage & TGF- $\beta 1$ & Rabbit articular chondrocytes & - & {$[148]$} \\
\hline $\begin{array}{l}\text { Chitosan-glycerol } \\
\text { phosphate hydrogel }\end{array}$ & Osteochondral & Autologous blood & - & $\begin{array}{l}\text { Rabbit } \\
\text { osteochondral defect }\end{array}$ & [149] \\
\hline $\begin{array}{l}\text { Chitosan/heparinoid } \\
\text { injectable hydrogels }\end{array}$ & Vascularization & FGF-2 & HUVEC & Mice back subcuits & {$[150]$} \\
\hline Chitosan hydrogels & Vascularization & FGF-2 & - & $\begin{array}{l}\text { Rabbit } \\
\text { myocardial infarction }\end{array}$ & {$[151]$} \\
\hline $\begin{array}{l}\text { Chitosan/chitin tubular device with } \\
\text { PLGA microspheres }\end{array}$ & $\begin{array}{l}\text { Peripheral } \\
\text { nerve regeneration }\end{array}$ & EGF & Mice neural stem cells & - & {$[152]$} \\
\hline Chitosan hydrogel & Skin & hEGF & - & Rat burn wounds & [139] \\
\hline Photocrosslinkable chitosan hydrogel & Skin & FGF-2 & - & $\begin{array}{l}\text { Mice full-thickness } \\
\text { skin incisions }\end{array}$ & {$[153]$} \\
\hline Particle aggregated chitosan scaffolds & Bone/cartilage & - & $\begin{array}{l}\text { Human adipose-derived } \\
\text { adult stem cells }\end{array}$ & - & {$[131]$} \\
\hline
\end{tabular}

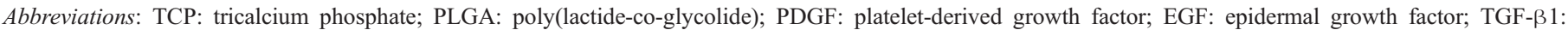
transforming growth factor- $\beta 1$; FGF-2: fibroblast growth factor-2; HUVEC: Human umbilical vein endothelial cells.

Compiled from references [131,135,139-153]. 


\subsection{Starch}

Starch is one of the most promising natural polymers because of its inherent biodegradability, overwhelming abundance and renewability. It is composed of a mixture of glycans that plants synthesize and deposited in the chloroplasts as their principal food reserve. Starch is stored as insoluble granules composed of $\alpha$-amylose $(20-30 \%)$ and amylopectin (70-80\%) [154]. $\alpha$ Amylose is a linear polymer of several thousands of glucose residues linked by $\alpha(1 \rightarrow 4)$ bonds. The $\alpha$-glycosidic bonds of $\alpha$ amylose cause it to adopt an helical conformation (left-handed helix) [154]. Amylopectin consists mainly of $\alpha(1 \rightarrow 4)$-linked glucose residues but it is a branched molecule with $\alpha(1 \rightarrow 6)$ branch points every 24 to 30 glucose residues in average. Amylopectin molecules contain up to $10^{6}$ glucose residues, making them some of the largest molecules in nature [154].

Starch by itself is extremely difficult to process and is brittle when used without the addition of a plasticizer. In most applications, the semi-crystalline native starch granule structure is either destroyed or reorganized, or both [155]. Water is the usual plasticizer in starch processing, and the physical properties of starch are greatly influenced by the amount of water present [155]. Therefore, the use of other plasticizers, such as low molecular weight alcohols, especially for the production of thermoplastic starches, renders starch more processable [155]. Additionally, blending two or more chemically and physically dissimilar natural polymers has shown potential to overcome these difficulties. Over the years several materials have been blended with starch to improve its processability, including, but not restricted to, several synthetic polymers, such as polyethylene [156], polycaprolactone [157], polyethylene-co-vinyl alcohol [158], poly(hydroxybutyrate-co-valerate) [159], among others $[160,161]$, or even other natural origin materials such as other polysaccharides [162] and proteins [163]. Starch has also been extensively modified by chemical methods such as oxidation [164] and grafting of acryl reactive groups [165]. Due to its degradation by amylases [166], this constitutes another strategy to tailor the degradation of starch-based materials $[167,168]$. A very important feature of most natural origin materials when considered for biomedical applications is the reaction of the host to degradation products (in the case of starch, degradation products are oligosaccharides that can be readily metabolized to produce energy).

Starch has been extensively used for drug delivery applications, including cancer therapy [169], nasal administration of insulin [170] among others [171,172]. Reis and co-workers $[173,174]$ have proposed starch-based materials (blends of starch with different synthetic polymers, such as ethylene vinyl alcohol, polylactic acid, cellulose acetate and polycaprolactone) as materials with potential for biomedical applications. Since then, others have studied the ability of these materials for biomedical applications, namely as porous scaffolds $[175,176]$. The work of Reis and co-workers has been focused on a wide range of biomedical applications, such as scaffolds for bone tissue engineering applications [174,177], bone cements $[178,179]$ and as drug delivery systems $[174,180-182]$. These materials have been shown to be biocompatible in vitro [183], and to possess a good in vivo performance [184]. More recently, these materials have been shown to permit the adhesion of endothelial cells [185], an indicator of the ability of starch-based fiber-based scaffolds to permit vascularization to occur. This finding builds on the already proven potential of these materials for tissue engineering applications.

Table 6 intends to summarize some relevant application of starch-based materials in the tissue engineering field and drug delivery.

\subsection{Alginate}

Alginate is one of the most studied and applied polysaccharidic polymers in tissue engineering and drug delivery field. They are abundant in nature and are found as structural components of marine brown algae and as capsular polysaccharides in some soil bacteria. Commercial alginates are extracted from three species of brown algae. These include Laminaria hyperborean, Ascophyllum nodosum, and Macrocystis pyrifera in which alginate comprises up to $40 \%$ of the dry weight [128]. Bacterial alginates have also been isolated from Azotobacter vinelandii and several Pseudomonas species [128]. Alginates are naturally derived polysaccharide block copolymers composed of regions of sequential $\beta$-D-mannuronic acid monomers (M-blocks), regions of $\alpha$-L-guluronic acid (G-

Table 6

Starch-based matrices/scaffolds for drug and cell delivery described for different tissue engineering applications

\begin{tabular}{|c|c|c|c|c|c|}
\hline $\begin{array}{l}\text { Polymer(s)/carrier/ } \\
\text { scaffold structure }\end{array}$ & TE application & Active biomolecule & $\begin{array}{l}\text { Encapsulated/seeded cell type } \\
\text { (source) }\end{array}$ & Animal model & References \\
\hline Starch-based porous scaffolds & Bone & Non-steroid anti-inflammatory agent & - & - & {$[174]$} \\
\hline Starch-based microparticles & Bone & Non-steroid anti-inflammatory agent & - & - & {$[180]$} \\
\hline Starch-based microparticles & Bone & Corticosteroids & - & - & {$[181]$} \\
\hline Starch-based microparticles & Bone & PDGF & - & - & {$[182]$} \\
\hline Starch-based microparticles & Bone & & Osteoblasts & - & {$[186]$} \\
\hline Starch-based fiber mesh scaffolds & Bone & & Bone marrow stromal cells & - & {$[187]$} \\
\hline Starch-based fiber mesh scaffolds & Vascularization & & $\begin{array}{l}\text { Micro (HPMEC-ST1.6R) and } \\
\text { macrovascular (HUVEC) } \\
\text { endothelial cells }\end{array}$ & - & {$[185]$} \\
\hline
\end{tabular}

Abbreviations: PDGF: platelet-derived growth factor.

Compiled from references [174,180-182,185-187]. 
blocks), and regions of interspersed $\mathrm{M}$ and $\mathrm{G}$ units [188]. The length of the M- and G-blocks and sequential distribution along the polymer chain varies depending on the source of the alginate. Alginates undergo reversible gelation in aqueous solution under mild conditions through interaction with divalent-cations such as $\mathrm{Ca}^{2+}$ that can cooperatively bind between the G-blocks of adjacent alginate chains creating ionic inter-chain bridges. This gentle property has led to their wide use as cell transplantation vehicles to grow new tissues and as wound dressings. Moreover, alginate as an anionic polymer with carboxyl end groups is a good mucoadhesive agent [128]. However, alginate hydrogels used in these applications have uncontrollable degradation kinetics and gels dissolve in an uncontrollable manner following the loss of divalent-cations releasing high and low molecular weight alginate units. Attempts have been made to covalently crosslink sodium alginate with gelatin and sodium tetraborate [189] or with albumin [190].

The hydrogel is formed because blocks of guluronic residues bind to cations resulting in a three dimensional network of alginate fibers held together with ionic interactions. The model that best describes this network is the "egg-box model" [191]. The resultant network is a function of the frequency and length of contiguous guluronic acid residues as well as the concentration and type of the cation [192]. The changes in frequency and length of adjacent guluronic acid units, as well as, changes in cation concentration can alter the number of alginate fibers held together changing the overall strength of the network. In a few words, alginates possessing a high guluronic acid content develop stiffer, more porous gels which maintain their integrity for longer periods of time. During cationic crosslinking, they do not undergo excessive swelling and subsequent shrinking, thus they better maintain their form [193]. On the other hand, alginates rich in mannuronic acid residues develop softer, less porous gels that tend to disintegrate with time. Consequently, they are characterized by a high degree of swelling and shrinking during cationic crosslinking [193].

The effects of alginate composition on the growth characteristics and metabolic activity of encapsulated cells have yet to be fully assessed. Nevertheless, the referred parameters that defined the alginate network strength may be the majority responsible for the differences in the growth characteristics of cells encapsulated in different alginates as reported since by Simpson and co-workers [193], as the network strength is a conditional parameter to the nutrient diffusion and cell-to-cell contact. The work of Yoon et al. [194] also reports the influence of alginate concentration and cell concentration in the expression of insulin-like growth factor-1 (IGF-1) of encapsulated chondrocytes.

Alginate-based materials are $\mathrm{pH}$-sensitive. Biomolecules release from alginate-based materials in low $\mathrm{pH}$ solutions is significantly reduced which could be advantageous in the development of a delivery system. Theoretically, alginate shrinks at low $\mathrm{pH}$ and the encapsulated drugs are not released. This $\mathrm{pH}-$ dependent behavior of alginate is exploited to tailor release profiles and in the development of 'smart' systems. However, at higher $\mathrm{pH}$ alginate undergoes a rapid dissolution which may result in burst release of protein drugs and subsequently their denaturation by proteolytic enzymes. Therefore, many modifications in the physicochemical properties are needed for the prolonged controlled release of protein drugs $[195,196]$.

Due to its biocharacteristics and the mild gelation process conditions, alginate templates are by far one of the natural origin polymers applied in tissue engineering applications even considering growth factor delivery or cell encapsulation, as Table 7 demonstrates. If one analyses the vast examples in the table, cartilage tissue engineering arises as the major application mainly to the need of the 3D culture of chondrocytes. Alginate beads/hydrogels can be prepared by extruding/maintaining a solution of sodium alginate containing the desired protein or cells, as droplets/blocks, in to a divalent crosslinking solution such as $\mathrm{Ca}^{2+}, \mathrm{Sr}^{2+}$, or $\mathrm{Ba}^{2+}$. Monovalent cations and $\mathrm{Mg}^{2+}$ ions do not induce gelation [128]. Although alginate beads/ hydrogels can be prepared by simple and mild procedures, this method has a major limitation that is the drug loss during bead/hydrogel preparation, by leaching through the pores in the beads/hydrogels.

One nature-inspired approach that has been attracting more attention is the use of biological multi-protein supplements as source of several growth factors to improve cell behavior. The biochemical stimulus provided in the initial critical stages of cell culture for engineered tissues may differ from that for single growth factor delivery. One example of this potential approach is given by Gaissmaier and co-workers [204] by using human platelet supernatant. As it is known, platelets are a rich source of many growth factors including transforming growth factor- $\beta$ and platelet-derived growth factor. However, the authors report that in spite of the addition of human platelet supernatant accelerate chondrocytes expansion can lead to their dedifferentiation. Other reported approach is the use of platelet-rich plasma isolated from autologous blood (porcine source) suggesting that the cells remain phenotypically stable in the presence of platelet-rich plasma [205]. Another strategy is proposed for angiogenic growth factors by using endothelial cell growth supplement [209] as source for vascular endothelial growth factor (VEGF), several endothelial cell growth factors (ECGFs) and basic fibroblast growth factor (bFGF). The study demonstrates that the controlled release of endothelial cell growth supplement leads to a two-fold increase in neovascularization at the material-tissue interface. However, the study does not include any comparison with the effect of any single growth factor.

For cartilage tissue engineering, periosteum can be use not only as source for chondrogenic growth factors but also as source for chondrogenic precursor cells as reported in the work of Stevens and colleagues [188]. Besides these, other advantage of periosteum over cell cultures for cartilage or osseous tissue engineering include the fact that it can serve as a template for directional evolution of tissue. The periosteum contains a source of chondrogenic growth factors that if supplemented in vitro by the morphogen TGF- $\beta 1$ can drive the terminal differentiation of the precursor cells into a chondrocyte phenotype [188]. The in vitro culture of periosteal explants within the alginate hydrogel, showed that after 6 weeks more than $50 \%$ of the total area of the periosteal explants was composed of cartilage that was hyaline- 
Table 7

Alginate-based matrices/scaffolds for drug and cell delivery described for different tissue engineering applications

\begin{tabular}{|c|c|c|c|c|c|}
\hline $\begin{array}{l}\text { Polymer(s)/carrier/ } \\
\text { scaffold structure }\end{array}$ & TE application & Active biomolecule & $\begin{array}{l}\text { Encapsulated/seeded cell type } \\
\text { (source) }\end{array}$ & Animal model & References \\
\hline Alginate-chitosan fibers & Not defined & Dexamethasone, PDGF-BB & - & - & {$[140]$} \\
\hline Alginate hydrogel & Bone/cartilage & BMP-2 gene & Bone marrow stromal cells & Mouse femoral muscle & {$[21]$} \\
\hline Alginate beads & Cartilage & BMP-2 & Human articular chondrocytes & - & {$[197]$} \\
\hline Alginate beads & Cartilage & IGF-1, TGF- $\beta 2$ and FGF-2 & Bovine articular chondrocytes & - & [198] \\
\hline Alginate beads & Cartilage & rhOP-1 (medium) & Bovine articular chondrocytes & - & [199] \\
\hline Alginate hydrogel and film & Cartilage & FGF-2 and TGF- $\beta$ (medium) & Rabbit periostal explants & - & {$[188,200]$} \\
\hline Alginate beads & Cartilage & BMP-2,4,5,6,7 & Chondrocytes (transfected) & $\begin{array}{l}\text { Nude mice } \\
\text { subcutaneous implantation }\end{array}$ & {$[201]$} \\
\hline Alginate beads & Cartilage & TGF- $\beta$ & - & $\begin{array}{l}\text { Rabbit knee } \\
\text { osteochondral defects }\end{array}$ & {$[202]$} \\
\hline Alginate hydrogel & Cartilage & $\begin{array}{l}\text { TGF- } \beta 1, \text { TGF- } \beta 2, \\
\text { TGF- } \beta 3 \text { or BMP-2 }\end{array}$ & $\begin{array}{l}\text { Bovine synovium-derived } \\
\text { progenitor cells }\end{array}$ & - & {$[203]$} \\
\hline Alginate beads & Cartilage & Human platelet supernatant & Human articular chondrocytes & - & [204] \\
\hline Alginate beads & Cartilage & Porcine platelet-rich plasma & Porcine articular chondrocytes & - & {$[205]$} \\
\hline Alginate beads & Vascularization & bFGF, VEGF, EGF & - & Rat myocardial infarction & {$[206]$} \\
\hline Alginate hydrogel & Vascularization & VEGF and bFGF & - & $\begin{array}{l}\text { Nude mice } \\
\text { subcutaneous implantation }\end{array}$ & [207] \\
\hline $\begin{array}{l}\text { Alginate beads with } \\
\text { bioactive glass }\end{array}$ & Vascularization & VEGF conditioned medium & $\begin{array}{l}\text { Human CCD-18Co fibroblast cells } \\
\text { and HDMECA }\end{array}$ & - & {$[208]$} \\
\hline $\begin{array}{l}\text { Alginate gels in PP and } \\
\text { PS hollow-fibers }\end{array}$ & Vascularization & $\begin{array}{l}\text { Endothelial cell } \\
\text { growth supplement }\end{array}$ & - & $\begin{array}{l}\text { Rat } \\
\text { subcutaneous implantation }\end{array}$ & {$[209]$} \\
\hline Alginate beads & $\begin{array}{l}\text { Peripheral } \\
\text { nerve regeneration }\end{array}$ & BDNF & - & Rat sciatic nerve & {$[210]$} \\
\hline $\begin{array}{l}\text { Alginate hydrogels with } \\
\text { RGD-containing peptides }\end{array}$ & Bone & BMP-2 and TGF- $\beta 3$ & Rat bone marrow stromal cells & $\begin{array}{l}\text { Nude mice } \\
\text { subcutaneous implantation }\end{array}$ & {$[211]$} \\
\hline Alginate hydrogel & Intervertebral disc & TGF- $\beta 1$ & Human intervertebral disc cells & - & {$[29,30,212]$} \\
\hline Alginate beads and disks & Cartilage & - & $\begin{array}{l}\text { Human adipose-derived adult } \\
\text { stem cells }\end{array}$ & $\begin{array}{l}\text { Nude mice } \\
\text { subcutaneous implantation }\end{array}$ & {$[48,213]$} \\
\hline Alginate hydrogel & Cartilage & Glucose (medium) & Cattle articular chondrocytes & - & {$[214]$} \\
\hline $\begin{array}{l}\text { Alginate freeze-dried } \\
\text { sponges and combined with } \\
\text { hyaluronic acid }\end{array}$ & Cartilage & - & Rat chondrocytes & $\begin{array}{l}\text { Rat full-thickness } \\
\text { cartilage defect }\end{array}$ & {$[215]$} \\
\hline $\begin{array}{l}\text { Alginate hydrogel } \\
\text { in Ethisorb210 }\end{array}$ & Cartilage & - & Bovine articular chondrocytes & $\begin{array}{l}\text { Nude mice } \\
\text { subcutaneous implantation }\end{array}$ & [216] \\
\hline Alginate hydrogel & Cartilage & - & Bovine articular chondrocytes & - & {$[101,194]$} \\
\hline $\begin{array}{l}\text { Alginate gel alone and } \\
\text { in PGA-PLA pads }\end{array}$ & Cartilage & - & Rabbit rib chondro-progenitor cells & $\begin{array}{l}\text { Rabbit knee } \\
\text { osteochondral defects }\end{array}$ & {$[217]$} \\
\hline $\begin{array}{l}\text { Alginate-chitosan } \\
\text { microcapsules }\end{array}$ & Bone/cartilage & - & $\begin{array}{l}\text { Human bone marrow cells and } \\
\text { human articular chondrocytes }\end{array}$ & $\begin{array}{l}\text { Nude mice } \\
\text { subcutaneous implantation }\end{array}$ & [218] \\
\hline $\begin{array}{l}\text { Oxidized alginate } \\
\text { injectable hydrogel }\end{array}$ & Liver & - & Rat hepatocytes & - & [189] \\
\hline Alginate beads & Pancreas & - & Murine insulinoma $\beta$ TC3 cells & - & {$[193]$} \\
\hline
\end{tabular}

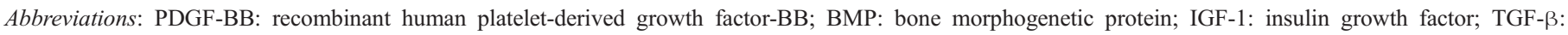

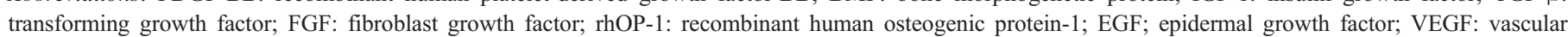

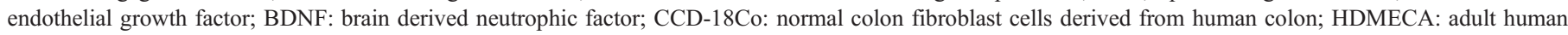

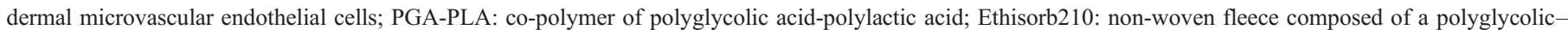
polylactic-copolymer punctually glued with polydioxanon; PP: polypropylene, PS: polysulfone.

Compiled from references [21,29,30,48,101,140,188,189,193,194,197-218].

like in appearance in contrast to the results obtained with encapsulated chondrocytes where constructs supported the in vitro culture for a period of several weeks but did not form a hyalinelike cartilaginous tissue [188].

Concerning the commercially available products, alginate has been widely marketed as wound dressings. Examples are Nu-Derm ${ }^{\circledR}$ commercialized by Johnson \& Johnson in USA, Curasorb ${ }^{\circledR}$ by Kendall or AlgiSite ${ }^{\circledR}$ by Smith \& Nephew in USA. Genialab in Germany is marketing geniaBeads ${ }^{\circledR}$ CA which are hydrogel beads made from calcium alginate. The hydrogel beads' size can be chosen from a wide range of 0.2 to
$3 \mathrm{~mm}$ to give them the desired properties regarding eye-appeal, release properties, or technical demands in general. A more tissue engineering driven product is commercialize by Articular Engineering LCC in USA for research purposes that has a variety of available products ranging engineered tissues, isolated cells, native tissues and cryopreserved cells from cartilage, synovium and intervertebral disc from both bovine or human origin using alginate beads with the alginate-recoveredchondrocyte or ARCTM method. A study was published on further development in this technology using osteogenic protein-1 [199]. 


\subsection{Hyaluronan}

Hyaluronic acid is most frequently referred to as hyaluronan due to the fact that it exists in vivo as a polyanion and not in the protonated acid form [219]. Hyaluronan is a naturally occurring non-sulfated glycosaminoglycan and a major macromolecular component of the intercellular matrix of most connective tissues such as cartilage, vitreous of the human eye, umbilical cord and synovial fluid [219]. Hyaluronic acid is a linear polysaccharide that consists of alternating disaccharide units of $\alpha-1,4-\mathrm{D}-$ glucuronic acid and $\beta-1,3-N$-acetyl-D-glucosamine, linked by $\beta(1 \rightarrow 3)$ bonds [220]. Hyaluronan and its associated networks have many physiological roles that include tissue and matrix water regulation, structural and space-filling properties, lubrication, and a number of macromolecular functions [219]. Especially for its enhanced viscoelastic properties, hyaluronan works as a lubricant and shock absorber in synovial fluid [124]. Hyaluronan has been widely studied for drug delivery, for dermal, nasal, pulmonary, parenteral, liposome-modified, implantable delivery devices and for gene delivery (reviewed in Liao et al. [219]). Hyaluronan for tissue engineering has been focused on cartilage, bone and osteochondral applications, most likely due to the fact that it is a major macromolecular component of the extracellular matrix. The most relevant applications are summarize in Table 8.

Commercially available hyaluronan is obtained from different sources, mainly by extraction from umbilical cord, rooster comb, synovial fluid, or vitreous humour. In addition, hyaluronic acid can be easily and controllably produced in large scales through microbial fermentation, from strains of bacteria such as Streptococci [219], enabling the scale-up of derived products and avoiding the risk of animal-derived pathogens. Hyaluronan is available for several applications, for lubrication and mechanical support for the joints in osteoarthritis (Hyalgan ${ }^{\circledR}$ and Hyalubrix ${ }^{\circledR}$ from Fidia in Italy; Artz $^{\circledR}$ from
Seikagaku Corporation in Japan) as a viscoelastic gel for surgery and wound healing (Bionect ${ }^{\circledR}$ from CSC Pharmaceutical in USA; Jossalind ${ }^{\circledR}$ from Hexal in Germany), for implantation of artificial intraocular lens (Healon ${ }^{\circledR}$ from OVD from Advanced Medical Optics in USA, Opegan $\mathrm{R}^{\circledR}$ from Seikagaku in Japan, Opelead ${ }^{\circledR}$ from Shiseido in Japan, Orthovisc $^{\circledR}$ from Anika in USA) and as culture media for use in in vitro fertilization (EmbryoGlue ${ }^{\circledR}$ from Vitrolife, USA) [219]. Hyaff ${ }^{\circledR}$ commercialized by Fidia in Italy has been widely used as a biomaterial for biomedical applications as described in Table 8. From a chemical standpoint, Hyaff ${ }^{\circledR}$ is a benzyl ester of hyaluronic acid and its main characteristics are that $\mathrm{HYAFF}^{\circledR}$ maintains the biological characteristics of the natural molecule from which1 it derives, the natural degradation of Hyaff ${ }^{\circledR}$ releases hyaluronic acid, which is then degraded through wellknown metabolic pathways and that depending on the levels of esterification (e.g. the percentage of carboxylic groups interested by the esterification reaction), it is possible to obtain polymers with different levels of hydrophobicity.

\subsection{Chondroitin sulphate}

Extracellular matrix components are valuable building blocks for the preparation of biomaterials involved in tissue engineering, especially if their biological, chemical and physical characteristics can be controlled. An example is chondroitin sulfate, one of the most physiologically important glycosaminoglycans. Glycosaminoglycans (GAGs) are found in the lubricating fluid of the joints and as components of cartilage, synovial fluid, bone, and heart valves. With the exception of hyaluronan, these polysaccharides are covalently linked to a protein core, thereby forming proteoglycans [231]. Biocharacteristics of GAGs include the binding and modulation of growth factors and cytokines, the inhibition of proteases, and the involvement in adhesion, migration, proliferation and

Table 8

Hyaluronan-based matrices/scaffolds for drug and cell delivery described for different tissue engineering applications

\begin{tabular}{|c|c|c|c|c|c|}
\hline $\begin{array}{l}\text { Polymer(s)/carrier/ } \\
\text { scaffold structure }\end{array}$ & TE application & Active biomolecule & $\begin{array}{l}\text { Encapsulated/seeded cell type } \\
\text { (source) }\end{array}$ & Animal model & References \\
\hline $\begin{array}{l}\text { Hyaluronic acid hydrogel } \\
\text { nanofiber scaffold }\end{array}$ & Not defined & Fibronectin & NIH 3 T3 fibroblasts & - & {$[221]$} \\
\hline Hyaluronan-alginate scaffold & Not defined & bFGF & - & - & {$[222]$} \\
\hline Hyaluronate gel & Bone/cartilage & BMP-2 gene & Bone marrow stromal cells & Mouse femoral muscle & {$[21]$} \\
\hline Hyaluronic acid gel & Vascularization & bFGF & - & Nude mice subcutaneous implantation & {$[223]$} \\
\hline Hyaluronan-methylcellulose & Spinal cord & - & - & Spinal cord injury & [224] \\
\hline $\begin{array}{l}\text { Hyaluronic acid }\left(\text { Hyaff }^{\circledR} 11\right) \\
\text { fibre scaffold }\end{array}$ & Cartilage & - & Chondrocytes & Nude mice subcutaneous implantation & {$[225]$} \\
\hline Hyaluronic acid hydrogel & Cartilage & - & Auricular chondrocytes & Nude mice subcutaneous implantation & [226] \\
\hline $\begin{array}{l}\left.\text { Hyaluronic acid (Hyaff }{ }^{\circledR} 11\right) \\
\text { non-woven mesh scaffold }\end{array}$ & Osteochondral & - & Bone marrow mesenchymal cells & Rabbit osteochondral knee lesion & {$[227]$} \\
\hline Hyaluronic acid (native) & Vascularization & DNA & HUVECs & Rat hind limb & {$[228]$} \\
\hline $\begin{array}{l}\left.\text { Hyaluronic acid (Hyaff }{ }^{\circledR} 11\right) \\
\text { non-woven scaffold }\end{array}$ & Vascularization & - & $\begin{array}{l}\text { Human saphenous vein } \\
\text { endothelial cells }\end{array}$ & - & [229] \\
\hline Hyaluronic acid membrane & Skin & - & Melanocytes, keratinocytes & - & {$[230]$} \\
\hline $\begin{array}{l}\left.\text { Hyaluronic acid (Hyaff }{ }^{\circledR} 11\right) \\
\text { sponge-Hyaluronic Acid coating }\end{array}$ & Adipose & - & Preadypocytes & Nude mice subcutaneous implantation & {$[34]$} \\
\hline
\end{tabular}

Abbreviations: BMP-2: bone morphogenetic protein-2; bFGF: basic fibroblast growth factor.

Compiled from references [21,34,221-230]. 
differentiation of cells [232]. Furthermore, GAGs are practically non-immunogenic and degrade to non-toxic oligosaccharides. These characteristics together with their defined physical and chemical characteristics make them very interesting materials for tissue engineering. Due to its GAG nature, chondroitin sulfate is an attractive natural-origin polymer applied essentially in cartilage tissue engineering. Nevertheless, and due to its biological properties (mainly the ability to interact with various growth-active molecules), is often used in other tissue engineering applications to valorize other polymers in order to interact with cells and proteins improving cell behavior of the developed materials.

Chondroitin sulfate consists of repeating disaccharide units of D-glucuronic acid and $\mathrm{N}$-acetyl galatosamine sulfated at either 4- or 6-positions [233]. Chondroitin sulfate can bind with core protein to produce highly absorbent aggregan, which is a major structure inside cartilage and acts as a shock absorber, or it can produce sydecan, which is a cell receptor which can interact with adhesion proteins, cells and the extracellular matrix (ECM) [233]. In vitro studies suggest that chondroitin sulfate is also able to increase matrix component production by human chondrocytes [234]. Furthermore, chondroitin sulfate proteoglycans have a critical role in regeneration and plasticity in the central nervous system as reviewed by Galtrey and Fawcett [235].

However, the readily water-soluble nature of chondroitin sulfate limits its application as a solid-state drug delivery vehicle. Therefore, it is usual to carry out a crosslinking treatment to tailor the properties of chondroitin sulfate as reported in several works $[233,236,237]$ or to combine it with other polymers, such as chitosan [238], gelatin and hyaluronan [239,240], collagen [241,242], poly(vinyl alcohol) [233] or poly-(lacticco-glycolic acid) [240] in order to produce more stable materials. Moreover, and since chondroitin sulfate in negatively charged, interaction with positively charged molecules such as polymers or growth factors is anticipated being a key issue to facilitate the design of delivery systems. For instances this characteristic is used to produce chondroitin sulfate-chitosan sponges as delivery systems for platelet-derived growth factorBB (PDGF-BB) for bone regeneration as reported by Jeong Park et al. [238] where this interaction shown to induce more prolonged release of the growth factor. As previously referred, due to its biocharacteristics, chondroitin sulfate has been used in some extent in the tissue engineering field, mainly in cartilage applications. The aim of the following in Table 9 is to show the diversified applications (besides cartilage) of this natural occurring polymer as carrier for growth factor or cell delivery in this field.

An interesting approach using chondroitin sulfate is proposed by Daamen et al. [245] by reporting the preparation of molecularly-defined collagen-elastin-glycosaminoglycan scaffolds. Given the large heterogeneity in the body's scaffolds, it is the purpose of this study to demonstrate that tailor-made, molecularly-defined scaffolds can be produced from the main components of the extracellular matrix using in this case highly purified collagen, elastin, and chondroitin sulfate in order to produce organ-specific scaffolds for tissue engineering. The developed scaffolds present the combination of adhesive

Table 9

Chondroitin sulfate-based matrices/scaffolds for drug and cell delivery used in different tissue engineering applications

\begin{tabular}{|c|c|c|c|c|c|}
\hline $\begin{array}{l}\text { Polymer(s)/carrier/ } \\
\text { scaffold structure }\end{array}$ & TE application & Active biomolecule & $\begin{array}{l}\text { Encapsulated/seeded cell type } \\
\text { (source) }\end{array}$ & Animal model & References \\
\hline Chondroitin 4-sulfate hydrogels & Not defined & $\begin{array}{l}\text { Vasopressin, aprotinin, } \\
\text { lysozyme, albumin }\end{array}$ & - & - & [243] \\
\hline $\begin{array}{l}\text { Chondroitin sulfate-collagen } \\
\text { coated discs }\end{array}$ & Bone & rhBMP-2 & - & Rat hind limbs & {$[242]$} \\
\hline Chondroitin sulfate-chitosan sponges & Bone & PDGF-BB & Rat calvarial cells & - & {$[238]$} \\
\hline $\begin{array}{l}\text { Chondroitin sulfate-collagen-chitosan } \\
\text { freeze-dried scaffolds with chitosan } \\
\text { microspheres }\end{array}$ & Cartilage & TGF- $\beta 1$ & Rabbit articular chondrocytes & - & [148] \\
\hline Chondroitin sulfate A & Vascularization & VEGF & Porcine vascular endothelial cells & - & {$[244]$} \\
\hline $\begin{array}{l}\text { Chondroitin sulfate } \\
\text { injectable hydrogels }\end{array}$ & Vascularization & bFGF & NIH $3 \mathrm{~T} 3$ fibroblasts & $\begin{array}{l}\text { Nude mice } \\
\text { subcutaneous implantation }\end{array}$ & [223] \\
\hline $\begin{array}{l}\text { Chondroitin sulfate-collagen-elastin } \\
\text { freeze-dried scaffolds }\end{array}$ & Not defined & - & $\begin{array}{l}\text { Human myoblasts and } \\
\text { human HFL1 lung fibroblasts }\end{array}$ & - & {$[245]$} \\
\hline $\begin{array}{l}\text { Chondroitin/gelatin hyaluronate-PLGA } \\
\text { porous scaffolds }\end{array}$ & Cartilage & - & $\begin{array}{l}\text { Rabbit mesenchymal } \\
\text { stem cells }\end{array}$ & $\begin{array}{l}\text { Rabbit full-thickness } \\
\text { cartilage defect }\end{array}$ & {$[240]$} \\
\hline $\begin{array}{l}\text { Chondroitin sulfate-gelatin-hyaluronan } \\
\text { freeze-dried scaffolds }\end{array}$ & Cartilage & - & Porcine articular chondrocytes & $\begin{array}{l}\text { Porcine full thickness } \\
\text { articular and } \\
\text { osteochondral defects }\end{array}$ & {$[239,246]$} \\
\hline Chondroitin sulfate-collagen scaffolds & Cartilage & - & Bovine articular chondrocytes & - & {$[247]$} \\
\hline Chondroitin sulfate-collagen hydrogels & Heart valve & - & Porcine VICs and VECs & - & {$[241]$} \\
\hline Chondroitin sulfate-PVA hydrogels & Kidney & - & $\begin{array}{l}\text { Baby-hamster kidney } \\
\text { (BHK) cells }\end{array}$ & - & [233] \\
\hline
\end{tabular}

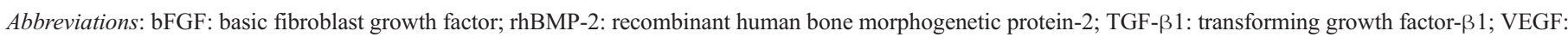

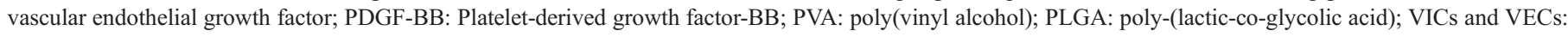
mitral valve interstitial cells (VICs) and endothelial cells (VECs);

Compiled from references [148,223,233,238-247]. 
properties and tensile strength of collagen with the elasticity of elastin (which is crucial for instances in blood vessels) and the bind capacity to growth-active molecules of chondroitin sulfate. This interesting approach is also one example of the effort that has to be done in trying to reduce the variability generally found of natural-origin polymers by using highly purified and characterized polymers producing molecularly-defined scaffolds.

In terms of commercially availability, chondroitin sulfate is widely marketed in USA and Europe as a nutritional supplement together with glucosamine used in the treatment of osteoarthritic patients. Chondroitin sulfate is also a component of the dermal layer of the FDA-approved skin substitute for treating burns [233]. An available commercial product is Integra ${ }^{\circledR}$ Dermal Regeneration Template marketed by Integra in USA which a bilayered membrane system for skin replacement that provides a scaffold for dermal regeneration. The dermal replacement layer is made of a porous matrix of fibers of crosslinked bovine tendon collagen and a glycosaminoglycan (chondroitin-6-sulfate) manufactured with a controlled porosity and defined degradation rate. According to the manufacturer, Integra ${ }^{\circledR}$ Dermal Regeneration Template is the first and only FDA-approved tissue engineered product for burn and reconstructive surgery. As hyaluronan, chondroitin sulfate is also used as a surgical aid in anterior segment procedures including cataract extraction and intraocular lens implantation. An example is Viscoat ${ }^{\circledR}$ from Alcon Laboratories in UK which is a solution of $4 \%$ chondroitin sulfate and $3 \%$ sodium hyaluronate.

\subsection{Other polysaccharidic polymers}

Other polysaccharides have been studied for tissue engineering applications. Some of them, the so-called cold set gels which form a gel on cooling the solution [124] like agarose, carrageenans and gellan gum have been studied in some extent the frame of drug delivery for tissue engineering and are described as follows. Due to their still narrow applications (but potential) as the drug delivery carriers in the tissue engineering field, the authors have chosen to overview them together in this section.

Dextran is a branched, high molecular weight polymer of Dglucose, produced by different bacterial strains from sucrose via the action of dextransucrase enzyme [248], consisting of $\alpha(1 \rightarrow 6)$-linked D-glucose residues with some degree of branching via $\alpha(1 \rightarrow 3)$ linkages. Dextran is readily available in a wide range of molecular weights along with several derivatives and it is biodegradable and biocompatible. These properties make it suitable for a whole range of applications, such as plasmaexpanders and blood substitutes, since it binds to erythrocytes, platelets and vascular endothelium by reducing their aggregation and adhesiveness, respectively. Additionally, it has also been shown to be a bone healing promoter and also for dermal and subcutaneous augmentation and for drug delivery [125].

Agar, the native polysaccharide of agarose, forms thermoreversible gels when dissolved in water. It consists of two main components, agarose and agaropectin. Agarose is a linear polysaccharide consisting on $(1 \rightarrow 3)-\beta$-D-galactopyranose- $(1 \rightarrow 4)$ 3,6 -anhydro- $\alpha$-L-galactopyranose as the basic unit and contains a few ionized sulfate groups [249]. Agarose is normally insoluble in organic solvents and cannot form gels. Apparently the gelling possibility in aqueous solutions is a consequence of the structure of water. The arrangement of the agarose chains that join together and adopt a double helix so tight that any gaps are closed, trapping any water inside the helix [249]. These double stranded helices are the result of specific intermolecular hydrogen bonding that contributes to the rigidity of the polymer chains [249]. Adding hydrogen bond decomposing agents like urea can have a tremendously negative effect on the gelling properties. Gelation occurs at temperatures below $40{ }^{\circ} \mathrm{C}$, whereas the melting temperature appears to be $90{ }^{\circ} \mathrm{C}$ [250]. The viscoelastic properties of aqueous agarose gels depend strongly on the degree of desulfation of its native polysaccharide agar: the propensity to form gels increases with increasing desulfation [250].

Carrageenans are a family of sulfated polysaccharides extracted from red marine algae and that are widely utilized in the industry because they can form reasonably stiff and thermoreversible gels in the presence of so-called gel-promoting salts at room temperature [251]. These polysaccharides are linear polymers consisting of chains of $(1 \rightarrow 3)$-linked $\beta$-D-galactose and $(1 \rightarrow 4)$-linked $\alpha$-D-galactose units which are variously substituted and modified to the 3,6-anhydro derivative, depending on the source and extraction conditions [113]. Three major types of carrageenan are recognized on the basis of their patterns of sulfate esterification: $\kappa$ (kappa), $\iota$ (iota), and $\lambda$ (lambda). All carrageenans are highly flexible molecules, which, at higher concentrations, wind around each other to form double-helical structures. A particular advantage is that they are thixotropic [252], i.e., they thin under shear stress and recover their viscosity once the stress is removed. Due to the strong ionic nature, these carrageenans exhibit a high degree of protein reactivity. These materials have been used in the field of drug delivery [253-255], which creates the potential for their use as drug delivery systems in tissue engineering. Carrageenans have been used mainly in the food industry, and several companies commercialize it - FMC BioPolymer or Carrageenan Company. Genialab in Germany is marketing geniaBeads ${ }^{\circledR}$ CG which are hydrogel beads made from carrageenan.

Gellan gum is a high molecular weight microbial exopolysaccharide produced by Pseudomonas elodea. It is a linear anionic heteropolysaccharide composed of the tetrasaccharide $(1 \rightarrow 4)$-L-rhamnose- $\alpha(1 \rightarrow 3)$-D-glucose- $\beta(1 \rightarrow 4)$-D-glucuronic acid- $\beta(1 \rightarrow 4)$-D-glucose as repeating unit, with carboxylic side groups. Gellan gum is widely used in the food industry thanks to its ability to form transparent gels resistant to heat and acid in comparison to other polysaccharide gels. In its native or high acyl form, two acyl substituents D-acetate and D-glycerate are present. Both substituents are located in the same glucose residue. The high acyl form produces transparent, soft, elastic and flexible gels which are resistant to heat and acid, whereas the low acyl form produces firm, non-elastic brittle [125]. Gel formation is due to a conformational heat-reversible transition from a state of single random macromolecules to a more ordered state where macromolecules pair with each other to form double helixes [125]. A single macromolecule can be involved in the 
formation of more than one helix. In this way junctions among the helixes are formed and consequently a gel is obtained [125]. Gellan gum has been studied for drug delivery applications, both as adjuvants [256] and as vehicle for drug delivery [257]. Its use for tissue engineering applications is taking the first steps, documented in Suri and Banerjee [258], where the authors have used a gellan gum gel as a substitute for the vitreous of the eye, and its properties were comparable to the commonly used material (silicone). Commercially available gellan gum, Gelrite ${ }^{\circledR}$, a novel ophthalmic vehicle, gels in the presence of mono- or divalent-cations present in the lacrimal fluid. It efficacy was comparable to marketed eye drops in efficacy of treatment of bacterial conjunctivitis that was induced artificially in rabbits [259]. Its properties, similar to other materials already studied in the tissue engineering field, make this material a suitable candidate for both cell encapsulation and drug delivery applications.

Cellulose is often referred as the most abundant organic polymer in the world [260] and therefore it is readily available and has a low cost. The ease in which it can be converted to derivatives makes it an attractive raw material [124]. In nature, it is the primary structural component of plant cell walls [261]. This is a linear polysaccharide of D-glucose units linked by $\beta(1 \rightarrow 4)$ glycosidic bonds $[261,262]$ where every other glucose residue is rotated approximately $180^{\circ}$ [262]. As a result, cellobiose is the structural repeating unit of the glucan chains in cellulose [262]. The glucan chains in cellulose are parallel to each other and are packed side by side to form microfibrils, which stabilizes the structure, minimizing its flexibility [263].
This highly cohesive, hydrogen-bonded structure, gives cellulose fibers exceptional strength and makes them water insoluble despite their hydrophilicity [263]. Cellulosic materials exhibit, however, poor degradation in vivo [264]. A cellulose sponge has been evaluated in rats' femurs for its permissibility for bone formation and it was found to need more time to regenerate than the control [265]. However, with growth factors' supplementation, this material can further display a desirable enhancement of bone formation. Several works have investigated the use of cellulose for cartilage [266,267], bone [268,269] and cardiac [264] applications. Hydroxypropylcellulose is a non-ionic water-soluble cellulose ether with a remarkable combination of properties. It combines organic-solvent solubility, thermoplasticity and surface activity. The molecular weight is varied by controlling the degree of polymerization of the cellulose backbone, which, in turn, controls the viscosity of hydroxypropylcellulose; as the degree of polymerization increases, the viscosity of the polymer increases. Hydroxypropylcellulose is used in pharmaceutical formulations for various purposes: low-viscosity grades are used as tablet binders in immediaterelease dosage forms and medium- and high-viscosity grades are used in sustained-release matrix formulations. Hydroxyethylcellulose is a nonionic water-soluble polymer derived from cellulose. There is a commercially available hydroxyethylcellulose named Natrosol ${ }^{\circledR} 250 \mathrm{HX}$ distributed by Hercules in USA and has a degree of substitution of 1.5 (three hydroxyls substituted/two units). Genialab in Germany is also marketing geniaBeads ${ }^{\circledR}$ MC which are hydrogel beads made from modified cellulose.

Table 10

Polysaccharides-based matrices/scaffolds for drug, cell and gene delivery used in different tissue engineering applications

\begin{tabular}{|c|c|c|c|c|c|}
\hline $\begin{array}{l}\text { Polymer(s)/carrier/ } \\
\text { scaffold structure }\end{array}$ & TE application & Active biomolecule & $\begin{array}{l}\text { Encapsulated/seeded cell type } \\
\text { (source) }\end{array}$ & Animal model & References \\
\hline $\begin{array}{l}\text { Dextran beads } \\
\quad \text { (in Ca-P porous scaffolds) }\end{array}$ & Bone & rhBMP-2 & - & $\begin{array}{l}\text { Dog class III } \\
\text { furcation defect }\end{array}$ & [270] \\
\hline $\begin{array}{l}\text { Dextran/gelatin } \\
\text { hydrogel microspheres }\end{array}$ & Bone & IGF-I & - & Periodontal defect & [271] \\
\hline Dextran hydrogel porous scaffolds & $\begin{array}{l}\text { Guided cell and } \\
\text { axonal regeneration }\end{array}$ & $\begin{array}{l}\text { ECM-derived } \\
\text { peptides (adhesion) }\end{array}$ & $\begin{array}{l}\text { Primary embryonic chick dorsal } \\
\text { root ganglia cells }\end{array}$ & - & [272] \\
\hline $\begin{array}{c}\text { Carboxymethyl-Dextran } \\
\text { hydrogel membranes }\end{array}$ & Not defined & Lysozyme & - & - & [273] \\
\hline Agarose film & Cartilage & FGF-2 & Periostal explants & Rabbit knee & [200] \\
\hline Agarose gel & Bone/cartilage & BMP-2 gene & $\begin{array}{l}\text { Bone marrow } \\
\text { stromal cells (transfected) }\end{array}$ & Mouse femoral muscle & {$[21]$} \\
\hline Agarose sponge & Pancreas & Insulin & $\begin{array}{l}\text { Pancreatic islets and } \\
\text { insulinoma cells }\end{array}$ & - & [274] \\
\hline Agarose gel & Intervertebral disc & TGF- $\beta 1$ & Human intervertebral disc cells & - & {$[29,30,212]$} \\
\hline Agarose gel & Cartilage & - & Bovine articular chondrocytes & - & {$[101]$} \\
\hline Agarose-fibrin gel & Cornea & - & $\begin{array}{l}\text { Epithelial, stromal and } \\
\text { endothelial cells }\end{array}$ & Rabbit cornea & [275] \\
\hline Gellan gum $\left(\right.$ Gelrite $\left.^{\mathbb{R}}\right)$ & Ophthalmology & Antibiotic & - & $\begin{array}{l}\text { Rabbit } \\
\text { bacterial conjunctivitis }\end{array}$ & [259] \\
\hline Gellan gum hydrogel & Eye (vitreous) & - & - & - & [258] \\
\hline Cellulose hollow-fibers & Not defined & Fibronectin & $\begin{array}{l}\text { Bovine coronary artery } \\
\text { smooth muscle cells }\end{array}$ & - & {$[276]$} \\
\hline Cellulose porous scaffold & Cartilage & - & $\begin{array}{l}\text { Bovine and } \\
\text { human chondrocytes }\end{array}$ & - & [277] \\
\hline
\end{tabular}

Abbreviations: rhBMP-2: recombinant human bone morphogenetic protein-2; IGF-1: insulin growth factor-I; ECM: extracellular matrix; FGF-2: fibroblast growth factor-2; BMP-2: bone morphogenetic protein-2; TGF- $\beta 1$ : transforming growth factor- $\beta 1$.

Compiled from references $[21,29,30,101,200,212,258,259,270-277]$. 
The following in Table 10 present some relevant examples of the previously described polysaccharidic polymers as matrices or scaffolds in the tissue engineering field.

\section{Polyhydroxyalkanoates}

In nature, a special group of polyesters is produced by a wide variety of microorganisms as an internal carbon and energy storage, as part of their survival mechanism [278]. Poly( $\beta$ hydroxybutyrate) (PHB) was first mentioned in the scientific literature as early as 1901 [1]. Bacterially synthesized polyhydoxyalkanoates (PHAs) have attract much attention because they can be produced from a variety of renewable resources, and are truly biodegradable and highly biocompatible thermoplastic materials [1]. Although a great variety of materials of this family can be produced, the use of PHAs in tissue engineering has been mainly restricted to PHBs and poly(hydroxybutyrateco-valerate) (PHBV) [279,280]. The brittleness of PHB was improved through copolymerization of $\beta$-hydroxybutyrate with $\beta$-hydroxyvalerate [281], which was first commercialized in 1990, but the high price of PHBV is still the major barrier to its wide spread usage [1]. The copolymerization produces less crystalline, more flexible and more readily processable materials than pure PHB. Depending on the requirements of different applications, PHA can be either blended, surface modified or combined with other polymers, enzymes or even inorganic materials, such as hydroxylapatite, to further adjust their mechanical properties or biocompatibility [279]. Interesting physical properties of polyhydroalkanoates include nonlinear optical activity and piezoelectricity [282], i.e. the capacity of a material to suffer electric polarization due to mechanical stress. Such properties can be very useful to tailor the material in question, increasing further promise applications of these polymers in areas such as tissue engineering and drug delivery. Nevertheless, polyhydroxybutyrates have already been studied to some extent for tissue engineering applications [279], mainly for scaffold materials in combination with ceramic materials [283285], as a vehicle for drug delivery [286,287] and also as a material for cardiac tissue engineering [288].

Commercially available PHBs (poly- $\beta$-hydroxybutyrate homopolymer) BIOPOLGO4 is commercialized by IC1 Biological Products in the form of compression-molded sheets $0.5 \mathrm{~mm}$ thick. Similarly, ICI commercialized BIOPOLP05, the co-polymer poly( $\beta$-hydroxybutyrate-co- $\beta$-hydroxyvalerate) containing $24 \%$ hydroxyvalerate.

\section{Final remarks and future directions}

Natural origin polymers have received considerable interest for drug delivery and tissue engineering applications. However, the combination of both applications into a single material has proven to be very challenging. This paper reviews the properties of natural-origin materials that render them attractive for applications where the combination of a scaffold material and a carrier for an active biomolecules is desirable. We also review research works were this combination of properties has been described, and summarize them in comprehensive tables for each polymer. The described systems include mainly growth factors delivery or cell carriers with application in the tissue engineering field targeting, as described, a range of biological living tissues. The most relevant properties for the aimed applications of the natural-origin polymers were described with a special focus in the description of protein-based polymers and polysaccharides due to their similarity with the extracellular matrix. The use of porous scaffolds, microparticles, membranes, hydrogels and injectable systems from such kind of materials is also focused, especially on what concerns to the present status of the research in this field that should lead towards their final application. Some examples of commercially available naturalorigin polymers or systems that can find use in research or in the clinical were also identified and described. Moreover, the biological performance of the described systems based on naturalbased polymers is presented, based on several examples aiming at different clinical-relevant applications.

Although natural origin materials present some drawbacks namely the difficulties in controlling the variability from batch to batch, mechanical properties or limited processability, their advantages clearly surplus the drawbacks. Their degradability, biocompatibility, low cost and availability, similarity with the extracellular matrix and intrinsic cellular interaction makes them attractive very candidates for biomedical applications, in particular as drug delivery systems for tissue engineering applications as described in this paper.

The aforementioned drawbacks are obviously limiting the widespread use of natural-origin polymers, mainly in clinical purposes. To try to overcome this disadvantage and for rational design of carriers/scaffolds for tissue engineering, it is essential to study the effect of individual components. To do so, templates have to be designed starting with highly purified molecules and the contribution of each component in the scaffold has to be controlled. Furthermore, when biomolecules such as growth factors are incorporated a further insightful study is needed in terms of interactions. Molecular design of these materials has clearly an important role in determining their suitability in such applications. Emerging technologies such as recombinant protein technologies and the development of molecularly-defined polymers can hinder this, by producing the polymer in a controlled, reliable and reproducible approach. A described example is the use of elastin-derived polypeptides or molecularly-defined polymers. Therefore, a better controlled development in methods for production, purification, or in material properties such as molecular weight, mechanical behavior or degradation rate is essential to widespread the use of these class of polymers.

In this paper, the authors have also presented some few examples of commercially available natural-origin products. However it is in some way limited because the availability of products with clinical relevance is still very narrowed especially if we limited the application to drug delivery field for tissue engineering applications. It is our conviction that a great deal of research work is still needed in order to obtain an increased number of commercially available and clinically successful natural-based systems and that emerging knowledge and technology is leading to a noteworthy exponential growth in this 
area. Undoubtedly, natural-origin polymers or nature-inspired materials appear as the natural and desired choice for the referred applications.

\section{Acknowledgments}

The authors acknowledge the financial support to the Portuguese Foundation for Science and Technology for the $\mathrm{PhD}$ Grant to Patrícia B. Malafaya (SFRH/BD/11155/2002), the European STREP HIPPOCRATES (NMP3-CT-2003-505758) and the European NoE EXPERTISSUES (NMP3-CT-2004500283).

\section{References}

[1] L. Yu, K. Dean, L. Li, Polymer blends and composites from renewable resources, Prog. Polym. Sci. 31 (2006) 576-602.

[2] J.C. Rodriguez-Cabello, J. Reguera, A. Girotti, M. Alonso, A.M. Testera, Developing functionality in elastin-like polymers by increasing their molecular complexity: the power of the genetic engineering approach, Prog. Polym. Sci. 30 (2005) 1119-1145.

[3] X.D. Guo, Q.X. Zheng, J.Y. Du, S.H. Yang, H. Wang, Z.W. Shao, E.J. Sun, Molecular tissue engineering: concepts, status and challenge, J. Wuhan Univ. Technol. 17 (2002) 30-34.

[4] H. Uludag, P. De Vos, P.A. Tresco, Technology of mammalian cell encapsulation, Adv. Drug Deliv. Rev. 42 (2000) 29-64.

[5] A. Chilkoti, T. Christensen, J.A. MacKay, Stimulus responsive elastin biopolymers: applications in medicine and biotechnology, Curr. Opin. Chem. Biol. 10 (2006) 652-657.

[6] A. Patel, B. Fine, M. Sandig, K. Mequanint, Elastin biosynthesis: the missing link in tissue-engineered blood vessels, Cardiovasc. Res. 71 (2006) 40-49.

[7] B. Chevallay, D. Herbage, Collagen-based biomaterials as 3D scaffolds for cell cultures: application for tissue engineering and gene therapy, Med. Biol. Eng. Comput. 38 (2000) 211-218.

[8] D.R. Eyre, Collagen: molecular diversity in the body's protein scaffold, Science 207 (1980) 1315-1322.

[9] P.D. Kemp, Tissue engineering and cell-populated collagen matrices, Methods Mol. Biol. 139 (2000) 287-293.

[10] C.H. Lee, A. Singla, Y. Lee, Biomedical applications of collagen, Int. J. Pharmacogn. 221 (2001) 1-22.

[11] C. Wong Po Foo, D.L. Kaplan, Genetic engineering of fibrous proteins: spider dragline silk and collagen, Adv. Drug Deliv. Rev. 54 (2002) 1131-1143.

[12] Y. Chunlin, P.J. Hillas, J.A. Buez, M. Nokelainen, J. Balan, J. Tang, R. Spiro, J.W. Polarek, The application of recombinant human collagen in tissue engineering, BioDrugs 18 (2004) 103-119.

[13] K.I. Kivirikko, Collagen biosynthesis: a mini-review cluster, Matrix Biol. 16 (1998) 355-356.

[14] R. Berisio, L. Vitagliano, L. Mazzarella, A. Zagari, Recent progress on collagen triple helix structure, stability and assembly, Prot. Pept. Lett. 9 (2002) 107-116.

[15] B. Brodsky, J.A. Ramshaw, The collagen triple-helix structure, Matrix Biol. 15 (1997) 545-554.

[16] P.F. Davidson, L. Levine, M.P. Drake, A. Rubin, S. Bump, The serologic specificity of tropocollagen telopeptides, J. Exp. Med. 126 (1967) 331-346.

[17] A.K. Lynn, I.V. Yannas, W. Bonfield, Antigenicity and immunogenicity of collagen, J. Biomed. Mater. Res., B. Appl. Biomater. 71B (2004) $343-354$.

[18] W. Friess, Collagen: biomaterial for drug delivery, Eur. J. Pharm. Biopharm. 45 (1998) 113-136.

[19] A. Letic-Gavrilovic, A. Piattelli, K. Abe, Nerve growth factor beta delivery via a collagen/hydroxyapatite composite and its effects on new bone growth, J. Mater. Sci., Mater. Med. 14 (2003) 95-102.
[20] T. Fujisato, T. Sajiki, Q. Liu, Y. Ikada, Effect of basic fibroblast growth factor on cartilage regeneration in chondrocyte-seeded collagen sponge scaffold, Biomaterials 17 (1996) 155-162.

[21] X.L. Xu, J. Lou, T.T. Tang, K.W. Ng, J.H. Zhang, C.F. Yu, K.R. Dai, Evaluation of different scaffolds for BMP-2 genetic orthopedic tissue engineering, J. Biomed. Mater. Res., B Appl. Biomater. 75B (2005) 289-303.

[22] L.A. Chandler, D.L. Gu, C.L. Ma, A.M. Gonzalez, J. Doukas, T. Nguyen, G.F. Pierce, M.L. Phillips, Matrix-enabled gene transfer for cutaneous wound repair, Wound Repair Regen. 8 (2000) 473-479.

[23] S. Koch, C. Yao, G. Grieb, P. Prevel, E.M. Noah, G.C.M. Steffens, Enhancing angiogenesis in collagen matrices by covalent incorporation of VEGF, J. Mater. Sci., Mater. Med. 17 (2006) 735-741.

[24] J. Pieper, T. Hafmans, P. Van Wachem, M. Van Luyn, L. Brouwer, J. Veerkamp, T. Kuppevelt, Loading of collagen-heparan sulfate matrices with bFGF promotes angiogenesis and tissue regeneration in rats, J. Biomed. Mater. Res. 62 (2002) 185-194.

[25] A.V. Vashi, K.M. Abberton, G.P. Thomas, W.A. Morrison, A.J. O'Connor, J.J. Cooper-White, E.W. Thompson, Adipose tissue engineering based on the controlled release of fibroblast growth factor- 2 in a collagen matrix, Tissue Eng. 12 (2006) 3035-3043.

[26] A. Batorsky, J.H. Liao, A.W. Lund, G.E. Plopper, J.P. Stegemann, Encapsulation of adult human mesenchymal stem cells within collagenagarose microenvironments, Biotechnol. Bioeng. 92 (2005) 492-500.

[27] Y. Xiao, H. Qian, W.G. Young, P.M. Bartold, Tissue engineering for bone regeneration using differentiated alveolar bone cells in collagen scaffolds, Tissue Eng. 9 (2003) 1167-1177.

[28] Y.R.V. Shih, C.N. Chen, S.W. Tsai, Y.J. Wang, O.K. Lee, Growth of mesenchymal stem cells on electrospun type I collagen nanofibers, Stem Cells 24 (2006) 2391-2397.

[29] H.E. Gruber, G.L. Hoelscher, K. Leslie, J.A. Ingram, E.N. Hanley, Threedimensional culture of human disc cells within agarose or a collagen sponge: assessment of proteoglycan production, Biomaterials 27 (2006) 371-376.

[30] H.E. Gruber, K. Leslie, J. Ingram, H.J. Norton, E.N. Hanley, Cell-based tissue engineering for the intervertebral disc: in vitro studies of human disc cell gene expression and matrix production within selected cell carriers, Spine J. 4 (2004) 44-55.

[31] Y. Sumita, M.J. Honda, T. Ohara, S. Tsuchiya, H. Sagara, H. Kagami, M. Ueda, Performance of collagen sponge as a 3-D scaffold for tooth-tissue engineering, Biomaterials 27 (2006) 3238-3248.

[32] R. Dorotka, U. Bindreiter, K. Macfelda, U. Windberger, Marrow stimulation and chondrocyte transplantation using a collagen matrix for cartilage repair, Osteoarthr. Cartil. 13 (2005) 655-664.

[33] L.D. Franceschi, B. Grigolo, L. Roseti, A. Facchini, M. Fini, G. Giavaresi, M. Tschon, R. Giardino, Transplantation of chondrocytes seeded on collagen-based scaffold in cartilage defects in rabbits, J. Biomed. Mater. Res., A 75A (2005) 612-622.

[34] K. Hemmrich, D.V. Heimburg, R. Rendchen, C.D. Bartolo, E. Milella, N. Pallua, Implantation of preadipocyte-loaded hyaluronic acid-based scaffolds into nude mice to evaluate potential for soft tissue engineering, Biomaterials 26 (2005) 7025-7037.

[35] Z. Xiang, R. Liao, M.S. Kelly, M. Spector, Collagen-GAG scaffolds grafted onto myocardial infarcts in a rat model: a delivery vehicle for mesenchymal stem cells, Tissue Eng. 12 (2006) 2467-2478.

[36] C. Danielsson, S. Ruault, A. Basset-Dardare, P. Frey, Modified collagen fleece, a scaffold for transplantation of human bladder smooth muscle cells, Biomaterials 27 (2006) 1054-1060.

[37] P.C. Wang, T. Takezawa, Reconstruction of renal glomerular tissue using collagen vitrigel scaffold, J. Biosci. Bioeng. 99 (2005) 529-540.

[38] Y. Tabata, Y. Ikada, Protein release from gelatin matrices, Adv. Drug Deliv. Rev. 31 (1998) 287-301.

[39] S. Young, M. Wong, Y. Tabata, A.G. Mikos, Gelatin as a delivery vehicle for the controlled release of bioactive molecules, J. Control. Release 109 (2005) 256-274.

[40] K.B. Djagny, Z. Wang, S. Xu, Gelatin: a valuable protein for food and pharmaceutical industries: review, Crit. Rev. Food Sci. Nutr. 41 (2001) $481-492$. 
[41] D. Olsen, C. Yang, M. Bodo, R. Chang, S. Leigh, J. Baez, D. Carmichael, M. Perala, E.-R. Hamalainen, M. Jarvinen, J. Polarek, Recombinant collagen and gelatin for drug delivery, Adv. Drug Deliv. Rev. 55 (2003) $1547-1567$.

[42] S.B. Ross-Murphy, Structure and rheology of gelatin gels: recent progress, Polymer 33 (1992) 2622-2627.

[43] L. Ren, A. Osaka, B. Yu, W. Shi, D.T. Ge, S. Chen, Q.Q. Zhang, Bioactive Gelatin-Siloxane Hybrids as Tissue Engineering Scaffolds, in: C.J. Sun, J. Ding, M. Gupta, G.M. Chow, L. Kurihara, L. Kabacoff (Eds.), Solid State Phenomena: Science and Technology Hybrid Materials, vol. 111, Trans Tech Publications, Switzerland, 2006, pp. 13-18.

[44] T.A. Holland, Y. Tabata, A.G. Mikos, In vitro release of transforming growth factor-betal from gelatin microparticles encapsulated in biodegradable, injectable oligo(poly(ethylene glycol) fumarate) hydrogels, J. Control. Release 91 (2003) 299-313.

[45] T.A. Holland, J.K.V. Tessmar, Y. Tabata, A.G. Mikos, Transforming growth factor-betal release from oligo(poly(ethylene glycol) fumarate) hydrogels in conditions that model the cartilage wound healing environment, J. Control. Release 94 (2004) 101-114.

[46] T.A. Holland, Y. Tabata, A.G. Mikos, Dual growth factor delivery from degradable oligo(poly(ethylene glycol) fumarate) hydrogel scaffolds for cartilage tissue engineering, J. Control. Release 101 (2005) 111-125.

[47] H. Park, J.S. Temenoff, T.A. Holland, Y. Tabata, A.G. Mikos, Delivery of TGF-beta1 and chondrocytes via injectable, biodegradable hydrogels for cartilage tissue engineering applications, Biomaterials 26 (2005) 7095-7103.

[48] H.A. Awad, M. Quinn Wickham, H.A. Leddy, J.M. Gimble, F. Guilak, Chondrogenic differentiation of adipose-derived adult stem cells in agarose, alginate, and gelatin scaffolds, Biomaterials 25 (2004) 3211-3222.

[49] T. Okamoto, Y. Yamamoto, M. Gotoh, C.-L. Huang, T. Nakamura, Y. Shimizu, Y. Tabata, H. Yokomise, Slow release of bone morphogenetic protein 2 from a gelatin sponge to promote regeneration of tracheal cartilage in a canine model, J. Thorac. Cardiovasc. Surg. 127 (2004) 329-334.

[50] T. Okamoto, Y. Yamamoto, M. Gotoh, D. Liu, M. Kihara, K. Kameyama, E. Hayashi, K. Nakamura, A. Yamauchi, C.L. Huang, H. Yokomise, M. Yamamoto, T. Nakamura, Y. Shimizu, Y. Tabata, Cartilage regeneration using slow release of bone morphogenetic protein-2 from a gelatin sponge to treat experimental canine tracheomalacia: a preliminary report, Asaio J. 49 (2003) 63-69.

[51] A. Ito, A. Mase, Y. Takizawa, M. Shinkai, H. Honda, K.-I. Hata, M. Ueda, T. Kobayashi, Transglutaminase-mediated gelatin matrices incorporating cell adhesion factors as a biomaterial for tissue engineering, J. Biosci. Bioeng. 95 (2003) 196-199.

[52] T. Masuda, M. Furue, T. Matsuda, Photocured, styrenated gelatin-based microspheres for de novo adipogenesis through corelease of basic fibroblast growth factor, insulin, and insulin-like growth factor I, Tissue Eng. 10 (2004) 523-535.

[53] Y. Kimura, M. Ozeki, T. Inamoto, Y. Tabata, Adipose tissue engineering based on human preadipocytes combined with gelatin microspheres containing basic fibroblast growth factor, Biomaterials 24 (2003) 2513-2521.

[54] R.G. Payne, J.S. McGonigle, M.J. Yaszemski, A.W. Yasko, A.G. Mikos, Development of an injectable, in situ crosslinkable, degradable polymeric carrier for osteogenic cell populations. Part 2. Viability of encapsulated marrow stromal osteoblasts cultured on crosslinking poly(propylene fumarate), Biomaterials 23 (2002) 4373-4380.

[55] R.G. Payne, M.J. Yaszemski, A.W. Yasko, A.G. Mikos, Development of an injectable, in situ crosslinkable, degradable polymeric carrier for osteogenic cell populations. Part 1. Encapsulation of marrow stromal osteoblasts in surface crosslinked gelatin microparticles, Biomaterials 23 (2002) 4359-4371.

[56] J. Malda, E. Kreijveld, J.S. Temenoff, C.A.V. Blitterswijk, J. Riesle, Expansion of human nasal chondrocytes on macroporous microcarriers enhances redifferentiation, Biomaterials 24 (2003) 5153-5161.

[57] M.S. Ponticiello, R.M. Schinagl, S. Kadiyala, F.P. Barry, Gelatin-based resorbable sponge as a carrier matrix for human mesenchymal stem cells in cartilage regeneration therapy, J. Biomed. Mater. Res. 52 (2000) 246-255.
[58] Y. Liu, X.Z. Shu, G.D. Prestwich, Osteochondral defect repair with autologous bone marrow derived mesenchymal stem cells in an injectable, in situ, cross-linked synthetic extracellular matrix, Tissue Eng. 12 (2006) 3405-3416.

[59] G.H. Altman, F. Diaz, C. Jakuba, T. Calabro, R.L. Horan, J. Chen, H. Lu, J. Richmond, D.L. Kaplan, Silk-based biomaterials, Biomaterials 24 (2003) 401-416.

[60] M.B. Hinman, J.A. Jones, R.V. Lewis, Synthetic spider silk: a modular fiber, Trends Biotech. 18 (2000) 374-379.

[61] Y. Tamada, New process to form a silk fibroin porous 3-D structure, Biomacromolecules 6 (2005) 3100-3106.

[62] S. Inoue, K. Tanaka, F. Arisaka, S. Kimura, K. Ohtomo, S. Mizuno, Silk friboin of Bombyx mori is secreted, assembling a high molecular mass elementary unit consisting of H-chain, L-chain and P25, with a 6:6:1 molar ratio, J. Biol. Chem. 275 (2000) 40517-40528.

[63] I. Dal Pra, G. Freddi, J. Minic, U. Armato, De novo engineering of reitcular connective tissue in vivo by silk fibroin nonwoven materials, Biomaterials 26 (2005) 1987-1999.

[64] R.L. Horan, K. Antle, A.L. Collette, Y. Wang, J. Huang, J.E. Moreau, In vitro degradation of silk fibroin, Biomaterials 26 (2005) 3385-3393.

[65] S. Hofmann, C. Foo, F. Rossetti, M. Textor, G. Vunjak-Novakovic, D.L. Kaplan, H.P. Merkle, L. Meinel, Silk fibroin as an organic polymer for controlled drug delivery, J. Control. Release 111 (2006) 219-227.

[66] S. Sofia, M.B. MacCarthy, G. Gronowiz, D.L. Kaplan, Functionalized silk based biomaterials, J. Biomed. Mater. Res. 54 (2001) 139-148.

[67] C. Li, C. Vepari, H.-J. Jin, H.J. Kim, D.L. Kaplan, Electrospun silk-BMP2 scaffolds for bone tissue engineering, Biomaterials 27 (2006) 3115-3124.

[68] M. Fini, A. Motta, P. Torricelli, G. Glavaresi, N.N. Aldini, M. Tschon, R. Giardino, C. Migliaresi, The healing of confined critical size cancellous defects in the presence of silk fibroin hydrogel, Biomaterials 26 (2005) 3527-3536.

[69] S. Fuchs, A. Motta, C. Migliaresi, C.J. Kirkpatrick, Outgrowth endothelial cells isolated and expanded from human peripheral blood progenitor cells for endothelialization as a potential source of autologous of silk fibroin biomaterials, Biomaterials 27 (2006) 5399-5408.

[70] R.E. Unger, K. Peters, M. Wolf, A. Motta, C. Migliaresi, C.J. Kirkpatrick, Endothelialization of a non-woven silk fibroin net for use in tissue engineering: growth and gene regulation of hunian endothelial cells, Biomaterials 25 (2004) 5137-5146.

[71] Y. Wang, U.-J. Kim, D.J. Blasioli, H.-J. Kim, D.L. Kaplan, In vitro cartilage tissue engineering with $3 \mathrm{D}$ porous aqueous-derived silk scaffolds and mesenchymal stem cells, Biomaterials 26 (2005) 7082-7094.

[72] B.M. Min, G. Lee, S.H. Kim, Y.S. Nam, T.S. Lee, Electrospinning of silk fibroin nanofibers and its effect on the adhesion and spreading of normal human keratinocytes and fibroblasts in vitro, Biomaterials 25 (2004) 1289-1297.

[73] Q. Lv, Q. Feng, K. Hu, F. Cui, Three-dimensional fibroin/collagen scaffolds derived from aqueous solution and the use for HepG2 culture, Polymer 46 (2005) 12662-12669.

[74] G.H. Altman, R.L. Horan, H.H. Lu, J.E. Moreau, I. Martin, J.C. Richmond, D.L. Kaplan, Silk matrix for tissue engineered anterior cruciate ligaments, Biomaterials 23 (2002) 4131-4141.

[75] R. Hino, M. Tomito, K. Yoshizato, The generation of germline transgenic silkworms for the production of biologically active recombinant fusion proteins of fibroin and human basic fibroblast growth factor, Biomaterials 27 (2006) 5715-5724.

[76] T. Aper, A. Schmidt, M. Duchrow, H.-P. Bruch, Autologous blood vessels engineered from peripheral blood sample, Eur. J. Vasc. Endovasc. Surg. 33 (2007) 33-39.

[77] M.R. Neidert, E.S. Lee, T.R. Oegema, R.T. Tranquillo, Enhanced fibrin remodeling in vitro with TGF-beta1, insulin and plasmin for improved tissue-equivalents, Biomaterials 23 (2002) 3717-3731.

[78] S.L. Rowe, S. Lee, J.P. Stegemann, Influence of thrombin concentration on the mechanical and morphological properties of cell-seeded fibrin hydrogels, Acta Biomaterialia 3 (2007) 59-67.

[79] A.S. Wolberg, Thrombin generation and fibrin clot structure, Blood Rev. 21 (2007) 131-142. 
[80] H. Schmoekel, J.C. Schense, F.E. Weber, K.W. Gratz, D. Gnagi, R. Muller, J.A. Hubbell, Bone healing in the rat and dog with nonglycosylated BMP-2 demonstrating low solubility in fibrin matrices, J. Orthop. Res. 22 (2004) 376-381.

[81] M. Ehrbar, A. Metters, P. Zammaretti, J.A. Hubbell, A.H. Zisch, Endothelial cell proliferation and progenitor maturation by fibrin-bound VEGF variants with differential susceptibilities to local cellular activity, J. Control. Release 101 (2005) 93-109.

[82] D. Le Nihouannen, L.L. Guehennec, T. Rouillon, P. Pilet, M. Bilban, P. Layrolle, G. Daculsi, Micro-architecture of calcium phosphate granules and fibrin glue composites for bone tissue engineering, Biomaterials 27 (2006) 2716-2722.

[83] J. Oju, R. Soo Hyun, C. Ji Hyung, B.-S. Kim, Control of basic fibroblast growth factor release from fibrin gel with heparin and concentrations of fibrinogen and thrombin, J. Control. Release 105 (2005) 249-259.

[84] S. Cox, M. Cole, B. Tawil, Behavior of human dermal fibroblasts in threedimensional fibrin clots: dependence on fibrinogen and thrombin concentration, Tissue Eng. 10 (2004) 942-954.

[85] W. Ho, B. Tawil, J.C.Y. Dunn, B.M. Wu, The behavior of human mesenchymal stem cells in 3D fibrin clots: dependence on fibrinogen concentration and clot structure, Tissue Eng. 12 (2006) 1587-1595.

[86] G. Wechselberger, R. Russell, M. Neumeister, T. Schoeller, H. PizaKatzer, C. Rainer, Successful transplantation of three tissue-engineered cell types using capsule induction technique and fibrin glue as a delivery vehicle, Plastic Reconst. Surg. 110 (2002) 123-129.

[87] S.M. Willerth, K.J. Arendas, D.I. Gottlieb, S.E. Sakiyama-Elbert, Optimization of fibrin scaffolds for differentiation of murine embryonic stem cells into neural lineage cells, Biomaterials 27 (2006) 5990-6003.

[88] J.T. Schantz, A. Brandwood, D. Hutmacher, H. Khor, K. Bittner, Osteogenic differentiation of mesenchymal progenitor cells in computer designed fibrin-polymer-ceramic scaffolds manufactured by fused deposition modeling, J. Mater. Sci., Mater. Med. 16 (2005) 807-819.

[89] D. Eyrich, F. Brandl, B. Appel, H. Wiese, G. Maier, M. Wenzel, R. Staudenmaier, A. Goepferich, T. Blunk, Long-term stable fibrin gels for cartilage engineering, Biomaterials 28 (2007) 55-65.

[90] C.J. Hunter, J.K. Mouw, M.E. Levenston, Dynamic compression of chondrocyte-seeded fibrin gels: effects on matrix accumulation and mechanical stiffness, Osteoarthr. Cartil. 12 (2004) 117-130.

[91] C. Perka, O. Schultz, K. Lindenhayn, R.S. Spitzer, M. Muschik, M. Sittinger, G.R. Burmester, Joint cartilage repair with transplantation of embryonic chondrocytes embedded in collagen-fibrin matrices, Clin. Exper. Rheumatol. 18 (2000) 13-22.

[92] E.D. Miller, G.W. Fisher, L.E. Weiss, L.M. Walker, P.G. Campbell, Dosedependent cell growth in response to concentration modulated patterns of FGF-2 printed on fibrin, Biomaterials 27 (2006) 2213-2221.

[93] B. Rai, S.H. Teoh, D.W. Hutmacher, T. Cao, K.H. Ho, Novel PCL-based honeycomb scaffolds as drug delivery systems for rhBMP-2, Biomaterials 26 (2005) 3739-3748.

[94] O. Jeon, S.-W. Kang, H.-W. Lim, J. Chung, B.-S. Kim, Long-term and zero-order release of basic fibroblast growth factor from heparinconjugated poly(1-lactide-co-glycolide) nanospheres and fibrin gel, Biomaterials 27 (2006) 1598-1607.

[95] O. Jeon, S.H. Ryu, J. Chung, B.-S. Kim, Control of basic fibroblast growth factor release from fibrin gel with heparin and concentrations of fibrinogen and thrombin, J. Control. Release (2005) 249-259.

[96] S.J. Taylor, J.W. McDonald, S.E. Sakiyama-Elbert, Controlled release of neurotrophin-3 from fibrin gels for spinal cord injury, J. Control. Release 98 (2004) 281-294.

[97] S.J. Taylor, E.S. Rosenzweig, J.W. McDonald III, S.E. Sakiyama-Elbert, Delivery of neurotrophin-3 from fibrin enhances neuronal fiber sprouting after spinal cord injury, J. Control. Release 113 (2006) 226-235.

[98] A.C. Lee, V.M. Yu, J.B. Lowe, M.J. Brenner, D.A. Hunter, S.E. Mackinnon, S.E. Sakiyama-Elbert, Controlled release of nerve growth factor enhances sciatic nerve regeneration, Exp. Neurol. 184 (2003) 295-303.

[99] S.E. Sakiyama-Elbert, J.A. Hubbell, Controlled release of nerve growth factor from a heparin-containing fibrin-based cell in growth matrix, J. Control. Release 69 (2000) 149-158.
[100] S.E. Sakiyama-Elbert, J.A. Hubbell, Development of fibrin derivatives for controlled release of heparin-binding growth factors, J. Control. Release 65 (2000) 389-402.

[101] J.K. Mouw, N.D. Case, R.E. Guldberg, A.H.K. Plaas, M.E. Levenston, Variations in matrix composition and GAG fine structure among scaffolds for cartilage tissue engineering, Osteoarthr. Cartil. 13 (2005) $828-836$.

[102] G.A. Ameer, T.A. Mahmood, R. Langer, A biodegradable composite scaffold for cell transplantation, J. Orthop. Res. 20 (2002) 16-19.

[103] C. Perka, R.S. Spitzer, K. Lindenhayn, M. Sittinger, O. Schultz, Matrixmixed culture: new methodology for chondrocyte culture and preparation of cartilage transplants, J. Biomed. Mater. Res. 49 (2000) 305-311.

[104] X.X. Shao, D.W. Hutmacher, S.T. Ho, J.C.H. Goh, E.H. Lee, Evaluation of a hybrid scaffold/cell construct in repair of high-load-bearing osteochondral defects in rabbits, Biomaterials 27 (2006) 1071-1080.

[105] A. Mol, M.I. van Lieshout, C.G. Dam-de Veen, S. Neuenschwander, S.P. Hoerstrup, F.P.T. Baaijens, C.V.C. Bouten, Fibrin as a cell carrier in cardiovascular tissue engineering applications, Biomaterials 26 (2005) 3113-3121.

[106] C. Buchta, H.C. Hedrich, M. Macher, P. Hocker, H. Redl, Biochemical characterization of autologous fibrin sealants produced by CryoSeal and Vivostat in comparison to the homologous fibrin sealant product Tissucol/Tisseel, Biomaterials 26 (2005) 6233-6241.

[107] Q. Lu, K. Ganesan, D.T. Simionescu, N.R. Vyavahare, Novel porous aortic elastin and collagen scaffolds for tissue engineering, Biomaterials 25 (2004) 5227-5237.

[108] L. Buttafoco, N.G. Kolkman, P. Engbers-Buijtenhuijs, A.A. Poot, P.J. Dijkstra, I. Vermes, J. Feijen, Electrospinning of collagen and elastin for tissue engineering applications, Biomaterials 27 (2006) 724-734.

[109] J.B. Leach, J.B. Wolinsky, P.J. Stone, J.Y. Wong, Crosslinked alphaelastin biomaterials: towards a processable elastin mimetic scaffold, Acta Biomaterialia 1 (2005) 155-164.

[110] H. Betre, S.R. Ong, F. Guilak, A. Chilkoti, B. Fermor, L.A. Setton, Chondrocytic differentiation of human adipose-derived adult stem cells in elastin-like polypeptide, Biomaterials 27 (2006) 91-99.

[111] B.F. Gibbs, A. Zougman, R. Masse, C. Mulligan, Production and characterization of bioactive peptides from soy hydrolysate and soyfermented food, Food Res. Int. 37 (2004) 123-131.

[112] P. Lodha, A.N. Netravali, Characterization of stearic acid modified soy protein isolate resin and ramie fiber reinforced 'green' composites, Compos. Sci. Tech. 65 (2005) 1211-1225.

[113] C.H. Tang, H. Wu, Z. Chen, X.Q. Yang, Formation and properties of glycinin-rich and beta-conglycinin-rich soy protein isolate gels induced by microbial transglutaminase, Food Res. Int. 39 (2006) 87-97.

[114] C.M. Vaz, L.A. de Graaf, R.L. Reis, A.M. Cunha, In vitro degradation behaviour of biodegradable soy plastics: effects of crosslinking with glyoxal and thermal treatment, Polym. Degrad. Stability 81 (2003) 65-74.

[115] N. Diftis, V. Kiosseoglou, Physicochemical properties of dry-heated soy protein isolate-dextran mixtures, Food Chem. 96 (2006) 228-233.

[116] J.J. Guan, A.Y. Qiu, X.Y. Liu, Y.F. Hua, Y.H. Ma, Microwave improvement of soy protein isolate-saccharide graft reactions, Food Chem. 97 (2006) 577-585.

[117] S.S. Silva, J.M. Oliveira, J.A. Mano, R.L. Reis, Physicochemical characterization of novel chitosan-soy protein/TEOS porous hybrids for tissue engineering applications, Mater. Sci. Forum (2006) 1000-1004

[118] N. Cao, Y. Fu, J. He, Mechanical properties of gelatin films cross-linked, respectively, by ferulic acid and tannin acid, Food Hydrocoll. 21 (2007) 575-584.

[119] S.E. Molina Ortiz, M.C. Puppo, J.R. Wagner, Relationship between structural changes and functional properties of soy protein isolatescarrageenan systems, Food Hydrocolloids 18 (2004) 1045-1053.

[120] K.J. Ryan, M.S. Brewer, Purification and identification of interacting components in a wheat starch-soy protein system, Food Chem. 89 (2005) $109-124$.

[121] C.M. Vaz, M. Fossen, R.F. van Tuil, L.A. de Graaf, R.L. Reis, A.M. Cunha, Casein and soybean protein-based thermoplastics and composites 
as alternative biodegradable polymers for biomedical applications, J. Biomed. Mater. Res. 65A (2003) 60-70.

[122] C.M. Vaz, P.F. Van Doeveren, R.L. Reis, A.M. Cunha, Soy matrix drug delivery systems obtained by melt-processing techniques, Biomacromolecules 4 (2003) 1520-1529.

[123] C.M. Vaz, P.F.N.M. van Doeveren, R.L. Reis, A.M. Cunha, Development and design of double-layer co-injection moulded soy protein based drug delivery devices, Polymer 44 (2003) 5983-5992.

[124] K. Nishinari, R. Takahashi, Interaction in polysaccharide solutions and gels, Curr. Opin. Colloid Interface Sci. 8 (2003) 396-400.

[125] M.G. Cascone, N. Barbani, C. Cristallini, P. Giusti, G. Ciardelli, L. Lazzeri, Bioartificial polymeric materials based on polysaccharides, J. Biomater. Sci., Polym. Ed. 12 (2001) 267-281.

[126] J. Venugopal, S. Ramakrishna, Applications of polymer nanofibers in biomedicine and biotechnology, Appl. Biochem. Biotechnol. 125 (2005) $147-157$.

[127] E. Khor, L.Y. Lim, Implantable applications of chitin and chitosan, Biomaterials 24 (2003) 2339-2349.

[128] M. George, T.E. Abraham, Polyionic hydrocolloids for the intestinal delivery of protein drugs: alginate and chitosan - a review, J. Control. Release 114 (2006) 1-14.

[129] Y. Huang, S. Onyeri, M. Siewe, A. Moshfeghian, S.V. Madihally, In vitro characterization of chitosan-gelatin scaffolds for tissue engineering, Biomaterials 26 (2005) 7616.

[130] V.R. Patel, M.M. Amiji, Preparation and characterization of freezedried chitosan-poly(ethylene oxide) hydrogels for site-specific antibiotic delivery in the stomach, Pharmac. Res. 13 (1996) 588-593.

[131] P.B. Malafaya, A. Pedro, A. Peterbauer, C. Gabriel, H. Redl, R. Reis, Chitosan particles agglomerated scaffolds for cartilage and osteochondral tissue engineering approaches with adipose tissue derived stem cells, J. Mater. Sci., Mater. Med. 16 (2005) 1077-1085.

[132] M. Julien, D.R. Letouneau, Y. Marois, A. Cardou, M.W. King, R. Guidoin, D. Chachra, J.M. Lee, Shelf-life of bioprosthetic heart valves: a structural and mechanical study, Biomaterials 18 (1997) 605-612.

[133] S.C. Chen, Y.C. Wu, F.L. Mi, Y.H. Lin, L.C. Yu, H.W. Sung, A novel pHsensitive hydrogel composed of $\mathrm{N}, \mathrm{O}$-carboxymethyl chitosan and alginate cross-linked by genipin for protein drug delivery, J. Control. Release 96 (2004) 285-300.

[134] A. Di Martino, M. Sittinger, M.V. Risbud, Chitosan: a versatile biopolymer for orthopaedic tissue-engineering, Biomaterials 26 (2005) 5983-5990.

[135] J.Y. Lee, S.H. Nam, S.Y. Im, Y.J. Park, Y.M. Lee, Y.J. Seol, C.P. Chung, S.J. Lee, Enhanced bone formation by controlled growth factor delivery from chitosan-based biomaterials, J. Control. Release 78 (2002) $187-197$.

[136] Y. Okamoto, R. Yano, K. Miyatake, I. Tomohiro, Y. Shigemasa, S. Minami, Effects of chitin and chitosan on blood coagulation, Carbohyd. Polym. 53 (2003) 337-342.

[137] D.K. Kweon, S.B. Song, Y.Y. Park, Preparation of water-soluble chitosan/heparin complex and its application as wound healing accelerator, Biomaterials 24 (2003) 1595-1601.

[138] H. Ueno, T. Mori, T. Fujinaga, Topical formulations and wound healing applications of chitosan, Adv. Drug Deliv. Rev. 52 (2001) 105-115.

[139] C. Alemdaroglu, Z. Degim, N. Celebi, F. Zor, S. Ozturk, D. Erdogan, An investigation on burn wound healing in rats with chitosan gel formulation containing epidermal growth factor, Burns 32 (2006) 319-327.

[140] I.C. Liao, A.C.A. Wan, E.K.F. Yim, K.W. Leong, Controlled release from fibers of polyelectrolyte complexes, J. Control. Release 104 (2005) 347-358.

[141] I.K. Park, J. Yang, H.J. Jeong, H.S. Bom, I. Harada, T. Akaike, S.I. Kim, C.S. Cho, Galactosylated chitosan as a synthetic extracellular matrix for hepatocytes attachment, Biomaterials 24 (2003) 2331-2337.

[142] J.J. Delgado, C. Evora, E. Sanchez, M. Baro, A. Delgado, Validation of a method for non-invasive in vivo measurement of growth factor release from a local delivery system in bone, J. Control. Release 114 (2006) 223-229

[143] Y. Zhang, X. Cheng, J. Wang, Y. Wang, B. Shi, C. Huang, X. Yang, T. Liu, Novel chitosan/collagen scaffold containing transforming growth factor-beta1 DNA for periodontal tissue engineering, Biochem. Biophys. Res. Commun. 344 (2006) 362-369.

[144] Y. Zhang, Y. Wang, B. Shi, X. Cheng, A platelet-derived growth factor releasing chitosan/coral composite scaffold for periodontal tissue engineering, Biomaterials 28 (2007) 1515-1522.

[145] Y. Jeong Park, Y. Moo Lee, S. Nae Park, S. Yoon Sheen, C. Pyoung Chung, S.J. Lee, Platelet derived growth factor releasing chitosan sponge for periodontal bone regeneration, Biomaterials 21 (2000) 153-159.

[146] T. Guo, J. Zhao, J. Chang, Z. Ding, H. Hong, J. Chen, J. Zhang, Porous chitosan-gelatin scaffold containing plasmid DNA encoding transforming growth factor-betal for chondrocytes proliferation, Biomaterials 27 (2006) 1095-1103.

[147] S.E. Kim, J.H. Park, Y.W. Cho, H. Chung, S.Y. Jeong, E.B. Lee, I.C. Kwon, Porous chitosan scaffold containing microspheres loaded with transforming growth factor-beta1: implications for cartilage tissue engineering, J. Control. Release 91 (2003) 365-374.

[148] J.E. Lee, K.E. Kim, I.C. Kwon, H.J. Ahn, S.-H. Lee, H. Cho, H.J. Kim, S.C. Seong, M.C. Lee, Effects of the controlled-released TGF-beta1 from chitosan microspheres on chondrocytes cultured in a collagen/chitosan/ glycosaminoglycan scaffold, Biomaterials 25 (2004) 4163-4173.

[149] A. Chevrier, C.D. Hoemann, J. Sun, M.D. Buschmann, Chitosanglycerol phosphate/blood implants increase cell recruitment, transient vascularization and subchondral bone remodeling in drilled cartilage defects, Osteoarthr. Cartil. 15 (2007) 316-327.

[150] M. Fujita, M. Ishihara, M. Simizu, K. Obara, T. Ishizuka, Y. Saito, H. Yura, Y. Morimoto, B. Takase, T. Matsui, M. Kikuchi, T. Maehara, Vascularization in vivo caused by the controlled release of fibroblast growth factor-2 from an injectable chitosan/non-anticoagulant heparin hydrogel, Biomaterials 25 (2004) 699-706.

[151] M. Fujita, M. Ishihara, Y. Morimoto, M. Simizu, Y. Saito, H. Yura, T. Matsui, B. Takase, H. Hattori, Y. Kanatani, M. Kikuchi, T. Maehara, Efficacy of photocrosslinkable chitosan hydrogel containing fibroblast growth factor-2 in a rabbit model of chronic myocardial infarction, J. Surg. Res. 126 (2005) 27-33.

[152] A. Goraltchouk, V. Scanga, C.M. Morshead, M.S. Shoichet, Incorporation of protein-eluting microspheres into biodegradable nerve guidance channels for controlled release, J. Control. Release 110 (2006) 400-407.

[153] K. Obara, M. Ishihara, T. Ishizuka, M. Fujita, Y. Ozeki, T. Maehara, Y. Saito, H. Yura, T. Matsui, H. Hattori, M. Kikuchi, A. Kurita, Photocrosslinkable chitosan hydrogel containing fibroblast growth factor-2 stimulates wound healing in healing-impaired $\mathrm{db} / \mathrm{db}$ mice, Biomaterials 24 (2003) 3437-3444.

[154] W.R. Morrison, J. Karkalas, Starch, in: P.M. Dey (Ed.), Methods in Plant Biochemistry: Carbohydrates, vol. 2, Academic Press Limited, London, 1990, pp. 323-352.

[155] K. Poutanen, P. Forssell, Modification of starch properties with plasticizers, Trends Polym. Sci. 4 (1996) 128-132.

[156] P.A. Dell, W.G. Kohlman, Effects of water-content on the properties of starch poly(ethylene vinyl alcohol) blends, J. Appl. Polym. Sci. 52 (1994) 353-363.

[157] C. Bastioli, A. Cerutti, I. Guanella, G.C. Romano, M. Tosin, Physical state and biodegradation behavior of starch-polycaprolactone systems, J. Environ. Polym. Degrad. 3 (1995) 81-95.

[158] M.A. Villar, E.L. Thomas, R.C. Armstrong, Rheological properties of thermoplastic starch and starch poly(ethylene-co-vinyl alcohol) blends, Polymer 36 (1995) 1869-1876.

[159] M.A. Kotnis, G.S. Obrien, J.L. Willett, Processing and mechanical properties of biodegradable poly(hydroxybutyrate-co-valerate)-starch compositions, J. Environ. Polym. Degrad. 3 (1995) 97-105.

[160] J.M. Mayer, G.R. Elion, C.M. Buchanan, B.K. Sullivan, S.D. Pratt, D.L. Kaplan, Biodegradable blends of cellulose-acetate and starch: production and properties, J. Macromol. Sci., Part A, Pure Appl. Chem. 32 (1995) 775-785.

[161] D. Trimnell, G.F. Fanta, Formulations prepared from polyacrylamide and starch, J. Polym. Mater. 11 (1994) 271-277.

[162] J. Nakamatsu, F.G. Torres, O.P. Troncoso, M.L. Yuan, A.R. Boccaccini, Processing and characterization of porous structures from chitosan and 
starch for tissue engineering scaffolds, Biomacromolecules 7 (2006) 3345-3355.

[163] A.K. Bajpai, J. Shrivastava, alpha-Amylase induced enhanced enzymatic degradation of binary polymeric blends of crosslinked starch and gelatin, J. Macromol. Sci., Part A, Pure Appl. Chem. 41 (2004) 949-969.

[164] I. Pashkuleva, A.P. Marques, F. Vaz, R.L. Reis, Surface modification of starch based blends using potassium permanganate-nitric acid system and its effect on the adhesion and proliferation of osteoblast-like cells, J. Mater. Sci., Mater. Med. 16 (2005) 81-92.

[165] K.M. Mostafa, Graft-polymerization of acrylic-acid onto starch using potassium-permanganate acid (redox system), J. Appl. Polym. Sci. 56 (1995) 263-269.

[166] G. Williamson, N.J. Belshaw, D.J. Self, T.R. Noel, S.G. Ring, P. Cairns, V.J. Morris, S.A. Clark, M.L. Parker, Hydrolysis of A-type and B-type crystalline polymorphs of starch by alpha-Amylase, beta-Amylase and Glucoamylase-1, Carbohyd. Polym. 18 (1992) 179-187.

[167] H.S. Azevedo, F.M. Gama, R.L. Reis, In vitro assessment of the enzymatic degradation of several starch based biomaterials, Biomacromolecules 4 (2003) 1703-1712.

[168] L. Tuovinen, S. Peltonen, M. Liikola, M. Hotakainen, M. LahtelaKakkonen, A. Poso, K. Jarvinen, Drug release from starch-acetate microparticles and films with and without incorporated alpha-amylase, Biomaterials 25 (2004) 4355-4362.

[169] R. Carter, T.G. Cooke, D. Hemingway, C.S. McArdle, W. Angerson, The combination of degradable starch microspheres and angiotensin-Ii in the manipulation of drug delivery in an animal-model of colorectal metastasis, Br. J. Cancer 65 (1992) 37-39.

[170] C. Callens, J.P. Remon, Evaluation of starch-maltodextrin-Carbopol 974P mixtures for the nasal delivery of insulin in rabbits, J. Control. Release 66 (2000) 215-220.

[171] C. Desevaux, V. Lenaerts, C. Girard, P. Dubreuil, Characterization of crosslinked high amylose starch matrix implants: 2. in vivo release of ciprofloxacin, J. Control. Release 82 (2002) 95-103.

[172] C. Sturesson, L.D. Wikingsson, Comparison of poly(acryl starch) and poly(lactide-co-glycolide) microspheres as drug delivery system for a rotavirus vaccine, J. Control. Release 68 (2000) 441-450.

[173] R.L. Reis, A.M. Cunha, Characterization of two biodegradable polymers of potential application within the biomaterials field, J. Mater. Sci., Mater. Med. 6 (1995) 786-792.

[174] M.E. Gomes, A.S. Ribeiro, P.B. Malafaya, R.L. Reis, A.M. Cunha, A new approach based on injection moulding to produce biodegradable starch-based polymeric scaffolds: morphology, mechanical and degradation behaviour, Biomaterials 22 (2001) 883-889.

[175] C.X.F. Lam, X.M. Mo, S.H. Teoh, D.W. Hutmacher, Scaffold development using 3D printing with a starch-based polymer, Mater. Sci. Eng., C, Biomim. Mater., Sens. Syst. 20 (2002) 49-56.

[176] F.G. Torres, A.R. Boccaccini, O.P. Troncoso, Microwave processing of starch-based porous structures for tissue engineering scaffolds, J. Appl. Polym. Sci. 103 (2007) 1332-1339.

[177] M.E. Gomes, J.S. Godinho, D. Tchalamov, A.M. Cunha, R.L. Reis, Alternative tissue engineering scaffolds based on starch: processing methodologies, morphology, degradation and mechanical properties, Mater. Sci. Eng., C, Biomim. Mater., Sens. Syst. 20 (2002) 19-26.

[178] L.F. Boesel, R.L. Reis, The effect of water uptake on the behaviour of hydrophilic cements in confined environments, Biomaterials 27 (2006) 5627-5633.

[179] I. Espigares, C. Elvira, J.F. Mano, B. Vazquez, J. San Roman, R.L. Reis, New partially degradable and bioactive acrylic bone cements based on starch blends and ceramic fillers, Biomaterials 23 (2002) 1883-1895.

[180] P.B. Malafaya, F. Stappers, R.L. Reis, Starch-based microspheres produced by emulsion crosslinking with a potential media dependent responsive behavior to be used as drug delivery carriers, J. Mater. Sci., Mater. Med. 17 (2006) 371-377.

[181] G.A. Silva, F.J. Costa, N.M. Neves, O.P. Coutinho, A.C.P. Dias, R.L. Reis, Entrapment ability and release profile of corticosteroids from starch-based particles, J. Biomed. Mater. Res. 73 (2005) 234-243.
[182] G.A. Silva, O.P. Coutinho, P. Ducheyne, I.M. Shapiro, R.L. Reis. Starchbased microparticles as vehicles for the delivery of active platelet-derived growth factor. Tissue Eng. (In Press).

[183] A.P. Marques, R.L. Reis, J.A. Hunt, The biocompatibility of novel starchbased polymers and composites: in vitro studies, Biomaterials 23 (2002) $1471-1478$.

[184] A.J. Salgado, O.P. Coutinho, R.L. Reis, J.E. Davies, In vivo response to starch-based scaffolds designed for bone tissue engineering applications, J. Biomed. Mater. Res., A 80A (2007) 983-989.

[185] M.I. Santos, S. Fuchs, M.E. Gomes, R.E. Unger, R.L. Reis, C.J. Kirkpatrick, Response of micro- and macrovascular endothelial cells to starch-based fiber meshes for bone tissue engineering, Biomaterials 28 (2007) 240-248.

[186] G.A. Silva, O.P. Coutinho, P. Ducheyne, I.M. Shapiro, R.L. Reis, The effect of starch and starch-bioactive glass composite microparticles on the adhesion and expression of the osteoblastic phenotype of a bone cell line, Biomaterials 28 (2007) 326-334.

[187] M.E. Gomes, R.L. Reis, A.G. Mikos, Bone tissue engineering constructs based on starch scaffolds and bone marrow cells cultured in a flow perfusion bioreactor, Adv. Mater. Forum 514-516 (2006) 980-984.

[188] M.M. Stevens, H.F. Qanadilo, R. Langer, V. Prasad Shastri, A rapidcuring alginate gel system: utility in periosteum-derived cartilage tissue engineering, Biomaterials 25 (2004) 887-894.

[189] B. Balakrishnan, A. Jayakrishnan, Self-cross-linking biopolymers as injectable in situ forming biodegradable scaffolds, Biomaterials 26 (2005) 3941-3951.

[190] D. Tada, T. Tanabe, A. Tachibana, K. Yamauchi. Albumin-crosslinked alginate hydrogels as sustained drug release carrier. Mater. Sci. Eng., C, Biomim. Mater., Sens. Syst. (In Press).

[191] K.I. Draget, G. Skjak-Braek, O. Smidsrod, Alginate based new materials, Int. J. Biol. Macromol. 21 (1997) 47-55.

[192] J.L. Drury, R.G. Dennis, D.J. Mooney, The tensile properties of alginate hydrogels, Biomaterials 25 (2004) 3187-3199.

[193] N.E. Simpson, C.L. Stabler, C.P. Simpson, A. Sambanis, I. Constantinidis, The role of the $\mathrm{CaCl}_{2}$-guluronic acid interaction on alginate encapsulated betaTC3 cells, Biomaterials 25 (2004) 2603-2610.

[194] D.M. Yoon, E.C. Hawkins, S. Francke-Carroll, J.P. Fisher, Effect of construct properties on encapsulated chondrocyte expression of insulinlike growth factor-1, Biomaterials 28 (2007) 299-306.

[195] C.K. Kuo, P.X. Ma, Ionically crosslinked alginate hydrogels as scaffolds for tissue engineering: part 1. structure, gelation rate and mechanical properties, Biomaterials 22 (2001) 511-521.

[196] T. Pongjanyakul, S. Puttipipatkhachorn, Xanthan-alginate composite gel beads: molecular interaction and in vitro characterization, Int. J. Pharm. 331 (2007) 61-71.

[197] T. Grunder, C. Gaissmaier, J. Fritz, R. Stoop, P. Hortschansky, J. Mollenhauer, W.K. Aicher, Bone morphogenetic protein-2 enhances the expression of type II collagen and aggrecan in chondrocytes embedded in alginate beads, Osteoarthr. Cartil. 12 (2004) 559-567.

[198] Y.M. Jenniskens, W. Koevoet, A.C.W. de Bart, H. Weinans, H. Jahr, J.A.N. Verhaar, J. DeGroot, G.J.V.M. van Osch, Biochemical and functional modulation of the cartilage collagen network by IGF1, TGFbeta2 and FGF2, Osteoarthr. Cartil. 14 (2006) 1136-1146.

[199] K. Masuda, B.E. Pfister, R.L. Sah, E.J.M.A. Thonar, Osteogenic protein1 promotes the formation of tissue-engineered cartilage using the alginate-recovered-chondrocyte method, Osteoarthr. Cartil. 14 (2006) 384-391.

[200] M.M. Stevens, R.P. Marini, I. Martin, R. Langer, V.P. Shastri, FGF-2 enhances TGF-beta1-induced periosteal chondrogenesis, J. Orthop. Res. 22 (2004) 1114-1119.

[201] C. Kaps, C. Bramlage, H. Smolian, A. Haisch, U. Ungethum, G.R. Burmester, M. Sittinger, G. Gross, T. Haupl, Bone morphogenetic proteins promote cartilage differentiation and protect engineered artificial cartilage from fibroblast invasion and destruction, Arthritis Rheum. 46 (2002) 149-162.

[202] C.M. Mierisch, S.B. Cohen, L.C. Jordan, P.G. Robertson, G. Balian, D.R. Diduch, Transforming growth factor-beta in calcium alginate beads for 
the treatment of articular cartilage defects in the rabbit, Arthrosc.-J. Arthrosc. Related Sur. 18 (2002) 892-900.

[203] Y. Park, M. Sugimoto, A. Watrin, M. Chiquet, E.B. Hunziker, BMP-2 induces the expression of chondrocyte-specific genes in bovine synovium-derived progenitor cells cultured in three-dimensional alginate hydrogel, Osteoarthr. Cartil. 13 (2005) 527-536.

[204] C. Gaissmaier, J. Fritz, T. Krackhardt, I. Flesch, W.K. Aicher, N. Ashammakhi, Effect of human platelet supernatant on proliferation and matrix synthesis of human articular chondrocytes in monolayer and threedimensional alginate cultures, Biomaterials 26 (2005) 1953-1960.

[205] K. Akeda, H.S. An, M. Okuma, M. Attawia, K. Miyamoto, E.J.M.A. Thonar, M.E. Lenz, R.L. Sah, K. Masuda, Platelet-rich plasma stimulates porcine articular chondrocyte proliferation and matrix biosynthesis, Osteoarthr. Cartil. 14 (2006) 1272-1280.

[206] H. Huwer, J. Winning, B. Vollmar, J. Rissland, C. Welter, H.-J. Schafers, M.D. Menger, Microvascularization and ventricular function after local alginate-encapsulated angiogenic growth factor treatment in a rat cryothermia-induced myocardial infarction model, Microvasc. Res. 62 (2001) 211-214.

[207] K.Y. Lee, M.C. Peters, D.J. Mooney, Comparison of vascular endothelial growth factor and basic fibroblast growth factor on angiogenesis in SCID mice, J. Control. Release 87 (2003) 49-56.

[208] H. Keshaw, A. Forbes, R.M. Day, Release of angiogenic growth factors from cells encapsulated in alginate beads with bioactive glass, Biomaterials 26 (2005) 4171-4179.

[209] H.K. Tilakaratne, S.K. Hunter, M.E. Andracki, J.A. Benda, V.G.J. Rodgers, Characterizing short-term release and neovascularization potential of multi-protein growth supplement delivered via alginate hollow fiber devices, Biomaterials 28 (2007) 89-98.

[210] E. Vogelin, J.M. Baker, J. Gates, V. Dixit, M.A. Constantinescu, N.F. Jones, Effects of local continuous release of brain derived neurotrophic factor (BDNF) on peripheral nerve regeneration in a rat model, Exp. Neurol. 199 (2006) 348-353.

[211] C.A. Simmons, E. Alsberg, S. Hsiong, W.J. Kim, D.J. Mooney, Dual growth factor delivery and controlled scaffold degradation enhance in vivo bone formation by transplanted bone marrow stromal cells, Bone 35 (2004) 562-569.

[212] H. Gruber, E. Fisher, B. Desai, A. Stasky, G. Hoelscher, E. Hanley, Human intervertebral disc cells from the annulus: three-dimensional culture in agarose or alginate and responsiveness to TGF-beta1, Exp. Cell Res. 235 (1997) 13-21.

[213] G.R. Erickson, J.M. Gimble, D.M. Franklin, H.E. Rice, H. Awad, F. Guilak, Chondrogenic potential of adipose tissue-derived stromal cells in vitro and in vivo, Biochem. Biophys. Res. Commun. 290 (2002) 763-769.

[214] H.K. Heywood, D.L. Bader, D.A. Lee, Glucose concentration and medium volume influence cell viability and glycosaminoglycan synthesis in chondrocyte-seeded alginate constructs, Tissue Eng. 12 (2006) 3487-3496.

[215] Y. Dausse, L. Grossin, G. Miralles, S. Pelletier, D. Mainard, P. Hubert, D. Baptiste, P. Gillet, E. Dellacherie, P. Netter, E. Payan, Cartilage repair using new polysaccharidic biomaterials: macroscopic, histological and biochemical approaches in a rat model of cartilage defect, Osteoarthr. Cartil. 11 (2003) 16-28.

[216] W.J.C.M. Marijnissen, G.J.V.M. van Osch, J. Aigner, S.W. van der Veen, A.P. Hollander, H.L. Verwoerd-Verhoef, J.A.N. Verhaar, Alginate as a chondrocyte-delivery substance in combination with a non-woven scaffold for cartilage tissue engineering, Biomaterials 23 (2002) 1511-1517.

[217] S.B. Cohen, C.M. Meirisch, H.A. Wilson, D.R. Diduch, The use of absorbable co-polymer pads with alginate and cells for articular cartilage repair in rabbits, Biomaterials 24 (2003) 2653-2660.

[218] J.C. Pound, D.W. Green, J.B. Chaudhuri, S. Mann, H.I. Roach, R.O.C Oreffo, Strategies to promote chondrogenesis and osteogenesis from human bone marrow cells and articular chondrocytes encapsulated in polysaccharide templates, Tissue Eng. 12 (2006) 2789-2799.

[219] Y.H. Liao, S.A. Jones, B. Forbes, G.P. Martin, M.B. Brown, Hyaluronan: pharmaceutical characterization and drug delivery, Drug Deliv. 12 (2005) $327-342$

[220] T.C. Laurent, U.B.G. Laurent, J.R.E. Fraser, Functions of hyaluronan, Ann. Rheum. Dis. 54 (1995) 429-432.
[221] Y. Ji, K. Ghosh, B.Q. Li, J.C. Sokolov, R.A.F. Clark, M.H. Rafailovich, Dual-syringe reactive electrospinning of cross-linked hyaluronic acid hydrogel nanofibers for tissue engineering applications, Macromol. Biosci. 6 (2006) 811-817.

[222] H.S. Nam, J. An, D.J. Chung, J.H. Kim, C.P. Chung, Controlled release behavior of bioactive molecules from photo-reactive hyaluronic acidalginate scaffolds, Macromol. Res. 14 (2006) 530-538.

[223] S. Cai, Y. Liu, X. Zheng Shu, G.D. Prestwich, Injectable glycosaminoglycan hydrogels for controlled release of human basic fibroblast growth factor, Biomaterials 26 (2005) 6054-6067.

[224] D. Gupta, C.H. Tator, M.S. Shoichet, Fast-gelling injectable blend of hyaluronan and methylcellulose for intrathecal, localized delivery to the injured spinal cord, Biomaterials 27 (2006) 2370-2379.

[225] J. Aigner, J. Tegeler, P. Hutzler, D. Campoccia, A. Pavesio, C. Hammer, E. Kastenbauer, A. Naumann, Cartilage tissue engineering with novel nonwoven structured biomaterial based on hyaluronic acid benzyl ester, J. Biomed. Mater. Res. 42 (1998) 172-181.

[226] C. Chung, J. Mesa, G.J. Miller, M.A. Randolph, T.J. Gill, J.A. Burdick, Effects of auricular chondrocyte expansion on neocartilage formation in photocrosslinked hyaluronic acid networks, Tissue Eng. 12 (2006) $2665-2673$.

[227] M. Radice, P. Brun, R. Cortivo, R. Scapinelli, C. Battaliard, G. Abatangelo, Hyaluronan-based biopolymers as delivery vehicles for bone-marrow-derived mesenchymal progenitors, J. Biomed. Mater. Res. 50 (2000) 101-109.

[228] Y.H. Yun, D.J. Goetz, P. Yellen, W.L. Chen, Hyaluronan microspheres for sustained gene delivery and site-specific targeting, Biomaterials 25 (2004) 147-157.

[229] N.J. Turner, C.M. Kielty, M.G. Walker, A.E. Canfield, A novel hyaluronan-based biomaterial (Hyaff-11) as a scaffold for endothelial cells in tissue engineered vascular grafts, Biomaterials 25 (2004) 5955-5964.

[230] E. Pianigiani, A. Andreassi, P. Taddeucci, C. Alessandrini, M. Fimiani, L. Andreassi, A new model for studying differentiation and growth of epidermal cultures on hyaluronan-based carrier, Biomaterials 20 (1999) 1689-1694.

[231] J.S. Pieper, A. Oosterhof, P.J. Dijkstra, J.H. Veerkamp, T.H. van Kuppevelt, Preparation and characterization of porous crosslinked collagenous matrices containing bioavailable chondroitin sulphate, Biomaterials 20 (1999) 847-858.

[232] L. Lippiello, Glucosamine and chondroitin sulfate: biological response modifiers of chondrocytes under simulated conditions of joint stress, Osteoarthr. Cartil. 11 (2003) 335-342.

[233] C.T. Lee, P.H. Kung, Y.D. Lee, Preparation of poly(vinyl alcohol)chondroitin sulfate hydrogel as matrices in tissue engineering, Carbohydr. Polym. 61 (2005) 348-354.

[234] C.T. Bassleer, J.P.A. Combal, S. Bougaret, M. Malaise, Effects of chondroitin sulfate and interleukin-1[beta] on human articular chondrocytes cultivated in clusters, Osteoarthr. Cartil. 6 (1998) 196-204.

[235] C.M. Galtrey, J.W. Fawcett. The role of chondroitin sulfate proteoglycans in regeneration and plasticity in the central nervous system. Brain Res. Rev. (In Press).

[236] A. Sintov, N. Di-Capua, A. Rubinstein, Cross-linked chondroitin sulphate: characterization for drug delivery purposes, Biomaterials 16 (1995) 473-478.

[237] S.C. Wang, B.H. Chen, L.F. Wang, J.S. Chen, Characterization of chondroitin sulfate and its interpenetrating polymer network hydrogels for sustained-drug release, Int. J. Pharmacogn. 329 (2007) 103-109.

[238] Y.J. Park, Y.M. Lee, J.Y. Lee, Y.J. Seol, C.P. Chung, S.J. Lee, Controlled release of platelet-derived growth factor-BB from chondroitin sulfatechitosan sponge for guided bone regeneration, J. Control. Release 67 (2000) 385-394.

[239] C.H. Chang, H.C. Liu, C.C. Lin, C.H. Chou, F.H. Lin, Gelatinchondroitin-hyaluronan tri-copolymer scaffold for cartilage tissue engineering, Biomaterials 24 (2003) 4853-4858.

[240] H. Fan, Y. Hu, C. Zhang, X. Li, R. Lv, L. Qin, R. Zhu, Cartilage regeneration using mesenchymal stem cells and a PLGA-gelatin/chondroitin/ hyaluronate hybrid scaffold, Biomaterials 27 (2006) 4573-4580. 
[241] T.C. Flanagan, B. Wilkins, A. Black, S. Jockenhoevel, T.J. Smith, A.S. Pandit, A collagen-glycosaminoglycan co-culture model for heart valve tissue engineering applications, Biomaterials 27 (2006) 2233-2246.

[242] D.S. Keskin, A. Tezcaner, P. Korkusuz, F. Korkusuz, V. Hasirci, Collagen-chondroitin sulfate-based PLLA-SAIB-coated rhBMP-2 delivery system for bone repair, Biomaterials 26 (2005) 4023-4034.

[243] M. Jensen, P. Birch Hansen, S. Murdan, S. Frokjaer, A.T. Florence, Loading into and electro-stimulated release of peptides and proteins from chondroitin 4-sulphate hydrogels, Eur. J. Pharm. Sci. 15 (2002) 139-148.

[244] Y. Liu, H. Yang, K. Otaka, H. Takatsuki, A. Sakanishi, Effects of vascular endothelial growth factor (VEGF) and chondroitin sulfate A on human monocytic THP-1 cell migration, Colloids Surf., B Biointerfaces 43 (2005) 216-220.

[245] W.F. Daamen, H.T.B. van Moerkerk, T. Hafmans, L. Buttafoco, A.A. Poot, J.H. Veerkamp, T.H. van Kuppevelt, Preparation and evaluation of molecularly-defined collagen-elastin-glycosaminoglycan scaffolds for tissue engineering, Biomaterials 24 (2003) 4001-4009.

[246] C.-H. Chang, T.-F. Kuo, C.-C. Lin, C.-H. Chou, K.-H. Chen, F.-H. Lin, H.-C. Liu, Tissue engineering-based cartilage repair with allogenous chondrocytes and gelatin-chondroitin-hyaluronan tri-copolymer scaffold: a porcine model assessed at 18, 24, and 36 weeks, Biomaterials 27 (2006) 1876-1888.

[247] J.L.C. van Susante, J. Pieper, P. Buma, T.H. van Kuppevelt, H. van Beuningen, P.M. van der Kraan, J.H. Veerkamp, W.B. van den Berg, R.P. H. Veth, Linkage of chondroitin-sulfate to type I collagen scaffolds stimulates the bioactivity of seeded chondrocytes in vitro, Biomaterials 22 (2001) 2359-2369.

[248] M. Naessens, A. Cerdobbel, W. Soetaert, E.J. Vandamme, Leuconostoc dextransucrase and dextran: production, properties and applications, J. Chem. Technol. Biotechnol. 80 (2005) 845-860.

[249] S. Arnott, A. Fulmer, W.E. Scott, I.C. Dea, R. Moorhouse, D.A. Rees, The agarose double helix and its function in agarose gel structure, J. Mol. Biol. 90 (1974) 269-284.

[250] D.A. Rees, Structure, conformation and mechanism in the formation of polysaccharide gels and networks, Adv. Carbohydr. Chem. 24 (1969) 267-332.

[251] M.R. Mangione, D. Giacomazza, D. Bulone, V. Martorana, G. Cavallaro, P.L. San Biagio, $\mathrm{K}+$ and $\mathrm{Na}+$ effects on the gelation properties of $\mathrm{k}$ carrageenan, Biophys. Chemist. 113 (2005) 129-135.

[252] A. Bartkowiak, D. Hunkeler, Carrageenan-oligochitosan microcapsules: optimization of the formation process, Colloid Surf., B Biointerfaces 21 (2001) 285-298.

[253] H. Sjoberg, S. Persson, N. Caram-Lelham, How interactions between drugs and agarose-carrageenan hydrogels influence the simultaneous transport of drugs, J. Control. Release 59 (1999) 391-400.

[254] C. Tapia, V. Corbalan, E. Costa, M.N. Gai, M. Yazdani-Pedram, Study of the release mechanism of diltiazem hydrochloride from matrices based on chitosan-alginate and chitosan-carrageenan mixtures, Biomacromolecules 6 (2005) 2389-2395.

[255] P. Vlieghe, T. Clerc, C. Pannecouque, M. Witvrouw, E. De Clercq, J.P. Salles, J.L. Kraus, Synthesis of new covalently bound kappa-carrageenan-AZT conjugates with improved anti-HIV activities, J. Med. Chem. 45 (2002) 1275-1283.

[256] U.O. Ike-Nor, S.I. Ofoefule, A. Chukwu, Evaluation of gellan gum as a potential pharmaceutical adjuvant: binding properties in tablets containing a poorly water soluble and poorly compressible drug, J. Drug Deliv. Sci. Technol. 16 (2006) 397-401.

[257] S.A. Agnihotri, S.S. Jawalkar, T.M. Aminabhavi, Controlled release of cephalexin through gellan gum beads: effect of formulation parameters on entrapment efficiency, size, and drug release, Eur. J. Pharm. Biopharm. 63 (2006) 249-261

[258] S. Suri, R. Banerjee, In vitro evaluation of in situ gels as short term vitreous substitutes, J. Biomed. Mater. Res., A 79A (2006) 650-664.

[259] Y. Sultana, M. Aqil, A. Ali, Ion-activated, Gelrite-based in situ ophthalmic gels of pefloxacin mesylate: comparison with conventional eye drops, Drug Deliv. 13 (2006) 215-219.
[260] R.M. Brown, Cellulose structure and biosynthesis: what is in store for the 21st century? J. Polym. Sci., A, Polym. Chem. 42 (2004) 487-495.

[261] I.M. Saxena, R.M. Brown, Cellulose biosynthesis: current views and evolving concepts, Ann. Bot. 96 (2005) 9-21.

[262] R.M. Brown, I.M. Saxena, K. Kudlicka, Cellulose biosynthesis in higher plants, Trends Plant Sci. 1 (1996) 149-156.

[263] C. Somerville, Cellulose synthesis in higher plants, Annu. Rev. Cell Dev. Biol. 22 (2006) 53-78.

[264] E. Entcheva, H. Bien, L.H. Yin, C.Y. Chung, M. Farrell, Y. Kostov, Functional cardiac cell constructs on cellulose-based scaffolding, Biomaterials 25 (2004) 5753-5762.

[265] M. Martson, J. Viljanto, T. Hurme, P. Saukko, Biocompatibility of cellulose sponge with bone, Eur. Surg. Res. 30 (1998) 426-432.

[266] F.A. Muller, L. Muller, I. Hofmann, P. Greil, M.M. Wenzel, R. Staudenmaier, Cellulose-based scaffold materials for cartilage tissue engineering, Biomaterials 27 (2006) 3955-3963.

[267] H. Pulkkinen, V. Tiitu, E. Lammentausta, E.R. Hamalainen, I. Kiviranta, M.J. Lammi, Cellulose sponge as a scaffold for cartilage tissue engineering, Biomed. Mater. Eng. 16 (2006) S29-S35.

[268] J. Holmbom, E. Ekholm, M. Martson, M. Liiho, J. Salonen, R. Penttinen, Cellulose and bioactive glass in bone tissue engineering, Bone 30 (2002) $5 \mathrm{~S}-5 \mathrm{~S}$.

[269] F.A. Muller, L. Jonasova, P. Cromme, C. Zollfrank, P. Greil, Biomimetic Apatite Formation on Chemically Modified Cellulose Templates, in: M.A. Barbosa, F.J. Monteiro, R. Correia, B. Leon (Eds.), Bioceramics 16, vol. 254-6, Trans Tech Publishers, Switzerland, 2004, pp. 1111-1114.

[270] F.M. Chen, Z.F. Wu, Q.T. Wang, H. Wu, Y.J. Zhang, X. Nie, Y. Jin, Preparation of recombinant human bone morphogenetic protein-2 loaded dextran-based microspheres and their characteristics, Acta Pharmacol. Sin. 26 (2005) 1093-1103.

[271] F.M. Chen, Y.M. Zhao, H. Wu, Z.H. Deng, Q.T. Wang, W. Zhou, Q. Liu, G.Y. Dong, K. Li, Z.F. Wu, Y. Jin, Enhancement of periodontal tissue regeneration by locally controlled delivery of insulin-like growth factor-I from dextran-co-gelatin microspheres, J. Control. Release 114 (2006) 209-222.

[272] S.G. Levesque, M.S. Shoichet, Synthesis of cell-adhesive dextran hydrogels and macroporous scaffolds, Biomaterials 27 (2006) 5277-5285.

[273] R.S. Zhang, M.G. Tang, A. Bowyer, R. Eisenthal, J. Hubble, A novel pHand ionic-strength-sensitive carboxy methyl dextran hydrogel, Biomaterials 26 (2005) 4677-4683.

[274] K. Bloch, V.I. Lozinsky, I.Y. Galaev, K. Yavriyanz, M. Vorobeychik, D. Azarov, L.G. Damshkaln, B. Mattiasson, P. Vardi, Functional activity of insulinoma cells (INS-1E) and pancreatic islets cultured in agarose cryogel sponges, J. Biomed. Mater. Res., A 75A (2005) 802-809.

[275] M. Alaminos, M.D. Sanchez-Quevdo, J.I. Munoz-Avila, D. Serrano, S Medialdea, I. Carreras, A. Campos, Construction of a complete rabbit cornea substitute using a fibrin-agarose scaffold, Invest. Ophthalmol. Visual Sci. 47 (2006) 3311-3317.

[276] I.K. Ko, H. Iwata, An Approach to Constructing Three-Dimensional Tissue, in: D. Hunkeler, A. Cherrington, A. Prokop, R. Rajotte (Eds.), Bioartificial Organs III: Tissue Sourcing, Immunoisolation, and Clinical Trials, vol. 944, The New York Academy of Sciences, New York, 2001, pp. 443-455.

[277] A. Svensson, E. Nicklasson, T. Harrah, B. Panilaitis, D.L. Kaplan, M. Brittberg, P. Gatenholm, Bacterial cellulose as a potential scaffold for tissue engineering of cartilage, Biomaterials 26 (2005) 419-431.

[278] I.L. Jung, K.H. Phyo, K.C. Kim, H.K. Park, I.G. Kim, Spontaneous liberation of intracellular polyhydroxybutyrate granules in Escherichia coli, Res. Microbiol. 156 (2005) 865-873.

[279] G.Q. Chen, Q. Wu, The application of polyhydroxyalkanoates as tissue engineering materials, Biomaterials 26 (2005) 6565-6578.

[280] S.F. Williams, D.P. Martin, D.M. Horowitz, O.P. Peoples, PHA applications: addressing the price performance issue in tissue engineering, Int. J. Biol. Macromol. 25 (1999) 111-121.

[281] P.P. King, Biotechnology: an industrial view, J. Chem. Technol. Biotechnol. 32 (1982) 2-8. 
[282] G.Q. Chen, Q. Wu, J.Z. Xi, H.P. Yu, Microbial production of biopolyesters-polyhydroxyalkanoates, Prog. Nat. Sci. 10 (2000) 843-850.

[283] C. Doyle, E.T. Tanner, W. Bonfield, In vitro and in vivo evaluation of polyhydroxybutyrate and of polyhydroxybutyrate reinforced with hydroxyapatite, Biomaterials 12 (1991) 841-847.

[284] J.C. Knowles, G.W. Hastings, H. Ohta, S. Niwa, N. Boeree, Development of a degradable composite for orthopedic use - in vivo biomechanical and histological evaluation of 2 bioactive degradable composites based on the polyhydroxybutyrate polymer, Biomaterials 13 (1992) 491-496.
[285] H.Y. Li, J. Chang, Fabrication and characterization of bioactive wollastonite/PHBV composite scaffolds, Biomaterials 25 (2004) $5473-5480$

[286] F. Koosha, R.H. Muller, Production of polyhydroxybutyrate (PHB) microparticles and nanoparticles, Arch. Pharm. 320 (1987) 913-913.

[287] F. Koosha, R.H. Muller, S.S. Davis, Polyhydroxybutyrate as a drug carrier, Crit. Rev. Ther. Drug Carr. Syst. 6 (1989) 117-130.

[288] R. Sodian, J.S. Sperling, D.P. Martin, A. Egozy, U. Stock, J.E. Mayer, J.P. Vacanti, Fabrication of a trileaflet heart valve scaffold from a polyhydroxyalkanoate biopolyester for use in tissue engineering, Tissue Eng. 6 (2000) 183-188. 